Article

\title{
Preparation and Characterization of Montmorillonite/PEDOT-PSS and Diatomite/PEDOT-PSS Hybrid Materials. Study of Electrochemical Properties in Acid Medium
}

\author{
Mohamed Kiari ${ }^{\mathbb{D}}$, Raúl Berenguer*(D), Francisco Montilla ${ }^{\mathbb{D}}$ and Emilia Morallón $\mathbb{D}$ \\ Instituto Universitario de Materiales, Departamento Química Física, Universidad de Alicante (UA), Apartado 99, \\ 03080 Alicante, Spain; kiarimohamed29@gmail.com (M.K.); francisco.montilla@ua.es (F.M.); \\ morallon@ua.es (E.M.) \\ * Correspondence: raul.berenguer@ua.es; Tel.: +34-965909150
}

Received: 11 April 2020; Accepted: 6 May 2020; Published: 8 May 2020

check for updates

\begin{abstract}
The hybridization of clay minerals with conducting polymers receives great interest for different potential applications, including environmental remediation. This work studies and compares the electrochemical properties of two different clays, montmorillonite (Mont) and diatomite (Diat), and their respective clay/PEDOT-PSS hybrid materials in $\mathrm{H}_{2} \mathrm{SO}_{4}$ medium. The hybrid materials were prepared by electropolymerization of EDOT in the presence of PSS. The physico-chemical and electrochemical properties of both clays were analyzed by different techniques, and the influence of the clay properties on electropolymerization and the electroactivity of the resulting clay/PEDOT-PSS hybrids was investigated. Specifically, the $\mathrm{Fe}^{2+} / \mathrm{Fe}^{3+}$ redox probe and the oxidation of diclofenac, as a model pharmaceutical emerging pollutant, were used to test the electron transfer capability and oxidative response, respectively, of the clay/PEDOT-PSS hybrids. The results demonstrate that, despite its low electrical conductivity, the Mont is an electroactive material itself with good electron-transfer capability. Conversely, the Diat shows no electroactivity. The hybridization with PEDOT generally enhances the electroactivity of the clays, but the clay properties affect the electropolymerization efficiency and hybrids electroactivity, so the Mont/PEDOT displays improved electrochemical properties. It is demonstrated that clay/PEDOT-PSS hybrids exhibit diclofenac oxidation capability and diclofenac concentration sensitivity.
\end{abstract}

Keywords: clay minerals; PEDOT; hybrid materials; electroactive materials; environmental remediation; diclofenac oxidation

\section{Introduction}

Clay minerals are highly abundant inexpensive materials with interesting properties for different applications [1,2]. Among them, clays generally exhibit high cationic exchange capacity and relatively high surface area, making them highly advantageous for the adsorption of metals and inorganic and organic pollutants in environmental remediation [3-7]. Of particular concern are the so-called emerging pollutants [8], including herbicides, pharmaceuticals, etc., which constitute potentially serious threats to human health and ecosystems. Hence, the development of clay-based materials for the removal and/or detection of emerging pollutants receives great interest.

In this context, electrochemical technologies gather unique advantages for environmental remediation [9], and have been found to be efficient for the degradation of emerging pollutants [10,11]. However, the use of clays in electrochemical applications is restricted because of their low conductivity [12]. 
The properties of clays can be improved by combination with other materials [13,14]. This is the case of conducting polymers, which gather the electrical and optical properties of metals and semiconductors, apart from low cost and weight, ease of synthesis and an extraordinary versatility to chemical structure design. As a result, conducting polymers receive great interest for their use in optoelectronic, photovoltaic, electrochromic, energy storage, (bio)sensing and bionic devices, among others. In this sense, clay/conducting polymers constitute an interesting family of hybrid materials that exhibit improved and/or novel properties for these and other applications [15-19].

Among conducting polymers, poly(3,4-ethylenedioxythiophene) (PEDOT) doped with poly-(styrenesulfonate) (PSS), the so called PEDOT-PSS, presents various advantages [20-22], demonstrating biocompatibility, high optical transparency in the visible light region, tunable and high electrical conductivity and excellent thermal stability in its doped state. Moreover, it shows good physical and chemical stability in air and high flexibility for flexible electronic devices. Accordingly, this polymer finds a wide range of applications [20-22]. Another interesting feature for practical applications is the easier solution processability of this polymer and its ability to form thin and homogeneous films. This is crucial for the preparation of conducting polymers in the form of coatings, i.e., the preferred conformation for multiple devices. In this sense, and although PEDOT-PSS is commercially available in the form of suspensions, the preferred technique for the synthesis of PEDOT-PSS coatings is the electropolymerization of EDOT [23]. In this process, EDOT is potentiostically or voltammetrically oxidized and the PSS acts as a surfactant to enhance the solubility of EDOT in water. At the same time, it serves as electrolyte to provide sufficient ionic conductivity. Finally, PSS is embebbed within the PEDOT chains, acting also as the doping agent. This technique enables a better reproducibility and precisely control of the film properties (morphology, thickness, etc.), through the control of the electrical charge passing through the electrode. Moreover, it has also been reported that electrodeposition leads to higher polymer conductivities than other preparation techniques, and it allows one to localize the polymer deposition only on specified conducting areas of the support.

The preparation and characterization of clay/thiophene-based polymer composites has been previously studied in the literature [24-42]. Most works have been addressed to study the intercalative (in situ) oxidative polymerization of thiophene-based monomers on unmodified and/or organically modified and/or exfoliated clays, the great majority of montmorillonites, by using $\mathrm{FeCl}_{3}$ [24-29], $\left(\mathrm{NH}_{4}\right)_{2} \mathrm{~S}_{2} \mathrm{O}_{8}$ [30] or $\mathrm{Fe}_{2}\left(\mathrm{SO}_{4}\right)_{3}$ [31] oxidants or simply by the oxidizing and/or acidic character of suitable clays [32-35]. On the other hand, other works were focused on the combination of already-synthesized polymers with the clays by solution intercalation [28,36]; colloidal interaction [37], solvent casting [25,27,38-40]; and melt-cool processing [38,39]. Finally, there are a couple of studies about the anodic polymerization of EDOT in the presence of bentonite [41,42]. However, despite the advantages of PEDOT-PSS and the electro-assisted polymerization method, very few studies have involved the synthesis of clay/PEDOT-PSS composites $[26,36,40]$ and none of them by electropolymerization. Moreover, the influence of the type of clay in a given syntetic route has not generally considered.

With respect to the electrochemical behavior and application of these composites, very few research works can be found in the literature [33,35,41,42]. Aradilla et al. [41] analyzed the voltammetric response of montmorillonite (MMT)-PEDOT composite in aqueous $0.1 \mathrm{M} \mathrm{LiClO}_{4}$, finding out that the clay enhances the ability to store charge but decreases the electrochemical stability of PEDOT. Nevertheless, these were very mild effects. Next, the authors evaluated the response of the composite for charge storage in supercapacitors, and showed that the asymmetric configuration of PEDOT and PEDOT-MMT films displayed higher specific capacitances than the respective symmetric ones [42].

In the other studies, electroactive species were introduced in the clays by ion-exchange prior to hybridization with PEDOT. Rajapakse et al. [33] found that the voltammetric profiles of PEDOT-Ce(III)-MMT and PEDOT-Ce(IV)-MMT composites, in $0.1 \mathrm{M} \mathrm{H}_{2} \mathrm{SO}_{4}$ aqueous electrolyte, are governed by the $\mathrm{Ce}(\mathrm{IV}) / \mathrm{Ce}(\mathrm{III})$ redox couple. On the other hand, Senarathna et al. demonstrated that $\mathrm{Co}(\mathrm{II}) / \mathrm{MMT} / \mathrm{PEDOT}$ composites exhibit good catalytic activity towards the oxygen reduction reaction 
(ORR), as well as the oxygen evolution reaction (OER) in aqueous $0.1 \mathrm{M} \mathrm{KOH}$, comparable to those of conventional and expensive $\mathrm{Pt} / \mathrm{C}$ catalysts, thus, being promising ORR catalysts for fuel cells [35].

Accordingly, in spite of the interest aroused by clay-/thiophene-based polymer composites, the electrochemical properties and potential electrode applications of these composites remain practically unexplored yet. Specifically, the electron transfer capability of these hybrid materials has been never studied, and their potential utilization in environmental electrochemical appplications, like the oxidation of pollutants, has rarely been investigated. This works studies the electrochemical behavior of two different common clays, a montmorillonite and a diatomite, before and after the preparation of the composite materials with PEDOT-PSS. The clay/PEDOT-PSS composites were synthesized by electropolymerization of EDOT on glassy carbon (GC)-supported clays in the presence of PSS. The electrochemical characterization was carried out in sulfuric acid medium. The influence of the distinct clays on the electron transfer capability of the clay/PEDOT-PSS hybrids, and their response towards the oxidation of diclofenac, as a model emerging pollutant, is analyzed and discussed.

\section{Materials and Methods}

\subsection{Materials}

Two commercial clays were used for this study, namely k10 montmorillonite $(97 \%$, Sigma-Aldrich, St. Louis, MO, USA) and diatomite (100\% diatomaceous earth from Spanish deposits, Castalia Bio, Almazora, Spain). The as-received clays were first sieved through a 100-micrometre size sieve to get clays with uniform particle size. These materials were denoted as Mont or Diat for the montmorillonite and diatomite samples, respectively.

Moreover, Nafion (5\%, Sigma-Aldrich, St. Louis, MO, USA), sulfuric acid (98\%, VWR Chemicals, Radnor, PA, USA), 3,4-ethylene dioxythiophene (EDOT) (97\%, Sigma-Aldrich, St. Louis, MO, USA), poly(sodium 4-styrene sulfonate) (PSS) (Sigma-Aldrich p.a., St. Louis, MO, USA), diclofenac (Sigma-Aldrich, St. Louis, MO, USA) and ultrapure water ( $18 \mathrm{M} \Omega / \mathrm{cm}$, from an Elga Lab (Lane End, High Wycombe, UK) water Purelab system) were used for the preparation of the solutions and materials.

\subsection{Preparation of Clay/PEDOT-PSS Hybrid Materials by Electrochemical Polymerization}

Clay/PEDOT-PSS hybrid materials were prepared by electropolymerization of EDOT in the presence of the clays. First, the clays were supported on the tip of a glassy carbon (GC) rod (geometric area $=0.07 \mathrm{~cm}^{2}$, Carbone Lorraine, model V-25) acting as current collector. To do this, $10-\mu \mathrm{L}$ aliquots of clay suspensions ( $0.5 \mathrm{~g}$ clay $+0.5 \mathrm{ml}$ ultrapure water $+5 \mu$ l Nafion) were dropped on a polished surface of GC. Next, the deposit was dried with a IR lamp for $3 \mathrm{~min}$. The deposition-drying procedure was repeated until reaching a given amount of supported clay, obtaining GC/clay electrodes. As will be justified below, for the electropolymerization experiments, 3 drops of the different clay suspensions (ca. $30 \mu \mathrm{g}$ clay) were deposited on the GC surface $\left(425 \mu \mathrm{g} / \mathrm{cm}^{2}\right)$.

Second, electrochemical polymerization of EDOT was carried on the GC-supported clays by cyclic voltammetry in a conventional three-electrode cell. The two different GC/clays acted as working electrodes, whereas a Pt wire and a $\mathrm{Ag} / \mathrm{AgCl} / \mathrm{Cl}-(3 \mathrm{M} \mathrm{KCl})$ electrode were used in all cases as counter and reference electrodes, respectively. An electrolyte solution of EDOT was prepared by dissolution of $53 \mu \mathrm{L}$ of EDOT, $1.46 \mathrm{~g}$ of PSS and $10.0 \mathrm{~mL}$ of ultrapure water under ultrasonication for $30 \mathrm{~min}$ at room temperature [43]. The polymerization was driven by cycling the electrode potential between -0.4 and $1.0 \mathrm{~V}$ up to 35 times at $100 \mathrm{mV} / \mathrm{s}$. After polymerization, the GC-supported Mont/PEDOT-PSS and Diat/PEDOT-PSS materials were rinsed with abundant ultrapure water, to remove excess monomers, PSS and/or small oligomers, for further characterization.

\subsection{Physico-Chemical Characterization of the Clays and Clay/PEDOT-PSS Hybrid Materials}

The physico-chemical properties of the different clays and clay/PEDOT-PSS materials were studied by several techniques. Field Emission Scanning Electron Microscopy (FESEM) was performed with a 
Merlin VP Compact device (ZEISS, Oberkochen, Germany) to obtain high resolution imaging of the different materials. Particularly, a fine carbon powder was sputter-coated on the clays (non-conductive materials) for their visualization by using a MED 020 high-vacuum coating system (Balzers Bal-Tec, Balzers, Liechtenstein), but this pre-treatment was not necessary for the clay/PEDOT-PSS materials. Moreover, transmission electron microscopy (TEM) images were collected with a JEM-2010 microscope (JEOL Ltd., Akishima, Tokio, Japan), working at $200 \mathrm{kV}$, to study the effect of ion-exchange and polymerization in the clay interlayer structure.

X-ray fluorescence (XRF) of the clays was carried out with $100 \mathrm{mg}$ of pelleted samples by using a PHILIPS MAGIX PRO spectrometer (PANalytical Inc., Westborough, MA, USA). For X-ray photoelectron spectroscopy (XPS), a K-Alpha spectrometer (Thermo-Scientific, Waltham, MA, USA) was used. The spectra were collected with $\mathrm{Al} \mathrm{K} \alpha$ radiation $(1486.6 \mathrm{eV})$, monochromatized by a twin crystal monochromator, yielding a focused elliptical X-ray spot (ca. $\left.0.314 \mathrm{~mm}^{2}\right)$ at $3 \mathrm{~mA} \times 12 \mathrm{kV}$. In-depth XPS analysis was performed by sputtering the sample with a $2 \mathrm{keV} \mathrm{Ar}^{+}$ion beam and a $\mathrm{Ta}_{2} \mathrm{O}_{5}$ pattern was used to estimate the etching depth. Charge compensation was achieved with the system flood gun. Surface elemental composition was calculated from background-substracted peak areas by using Avantage software. The deconvolution of XPS spectra was done by least squares using Lorentzian-Gaussian (L/G = $30 \%$ ) functions.

X-ray diffraction (XRD) measurements were carried out with a KRISTALLOFLEX K 760-80F diffractometer (Bruker D8-Advance, Billerica, MA, USA) by using a Ni-filtered $\mathrm{Cu} K \alpha$ radiation $(\lambda=1.5406 \AA)$ generated at $40 \mathrm{kV}$ and $40 \mathrm{~mA}$. Diffraction data points were recorded stepwise within $2 \theta=2.5^{\circ}-55.0^{\circ}$ at a scan rate of $1^{\circ} / \mathrm{min}$ with a scan step of $0.015^{\circ}$ in $2 \theta$.

The textural properties of the clays were analyzed by $\mathrm{N}_{2}$ adsorption-desorption isotherms (at -196 ${ }^{\circ} \mathrm{C}$ ) in a Quadrasorb-Kr/MP (Quantachrome Corporation, Boynton Beach, FL, USA) apparatus. Prior to analysis, the samples were outgassed for $8 \mathrm{~h}$ at $250^{\circ} \mathrm{C}$ under vacuum. The specific surface area $\left(\mathrm{S}_{\mathrm{BET}}\right)$ and the micropore volume $\left(\mathrm{V}_{\text {micro }}\right)$ were estimated by applying the BET and Dubinin-Radushkevich equations, respectively, to the $\mathrm{N}_{2}$ adsorption isotherm [44]. The mesopore volume $\left(\mathrm{V}_{\text {meso }}\right)$ was calculated as the difference between total pore volume $\left(\mathrm{V}_{0.995}\right.$, volume at relative pressure of 0.995$)$ and micropore volume $\left(\mathrm{V}_{\text {micro }}\right)[44]$.

\subsection{Electrochemical Characterization and Diclofenac Electro-Oxidation}

The electrochemical behavior of the clays and clay/PEDOT-PSS hybrid materials was studied in an electrochemical cell similar to that described in Section 2.2. However, a $0.5 \mathrm{M} \mathrm{H}_{2} \mathrm{SO}_{4}$ aqueous solution was used as the electrolyte in this case. For the characterization of the clays, GC/clay electrodes were prepared by deposition of clay suspensions (as explained in Section 2.2). The effect of the amount of deposited clay was analyzed. On the other hand, the GC-supported clay/PEDOT-PSS materials were characterized as prepared immediately after polymerization and washing (see Section 2.2). In addition, the electrochemical response of the GC support was also analyzed and used as the blank.

The different materials were characterized by cyclic voltammetry $(\mathrm{CV})$ between 0.2 and $0.7 \mathrm{~V}$ at $50 \mathrm{mV} / \mathrm{s}$. Next, the voltammetric measurements were repeated at varying scan rates (between 2.0 and $500 \mathrm{mV} \cdot \mathrm{s}^{-1}$ ). Furthermore, the voltammetric study at different scan rates was also performed in the presence of dissolved iron ( $0.01 \mathrm{M} \mathrm{FeSO}_{4}$ in $0.5 \mathrm{M} \mathrm{H}_{2} \mathrm{SO}_{4}$ aqueous electrolyte).

Finally, the potential application of these materials in the electro-oxidation of pollutants was investigated. Diclofenac was chosen as a example of pharmaceutic emerging pollutant. To do that, the GC-supported clays and clay/PEDOT-PSS materials were characterized in $0.5 \mathrm{M} \mathrm{H}_{2} \mathrm{SO}_{4}$ solutions containing differet diclofenac concentrations (20-200 ppm) between 0.2 and $1.7 \mathrm{~V}$ at $50 \mathrm{mV} / \mathrm{s}$.

The electrolyte solutions were initially de-aerated by $\mathrm{N}_{2}$ bubbling for ca. $20 \mathrm{~min}$ and isolated by flowing $\mathrm{N}_{2}$ during all the electrochemical experiments (included that of Section 2.2). All the cyclic voltammograms were recorded at room temperature by using a VSP potentiostat (Bio-logic Science Instruments, Seyssinet-Pariset, France). 


\section{Results}

\subsection{Physico-Chemical Characterization of the Clays}

The montmorillonite (Mont) consists of 1-10 $\mu \mathrm{m}$ irregular-shape particles (Figure 1A), which in turn are compact and non-uniform aggregates of smaller grains (Figure 1B). On the contrary, the diatomite (Diat) is made of individual or clumped fragments of particles with well-defined morphologies (Figure 1C). These characteristic shapes correspond to fossilized remains of diatoms, a type of hard-shelled microalgae. Although the sample may contain various species of diatomites, the most abundant or easily recognisable are triangle-shaped structues, like that of Figure 1D [45], with sizes ranging from 5 to $20 \mu \mathrm{m}$ and several pores of less than $100 \mathrm{~nm}$.
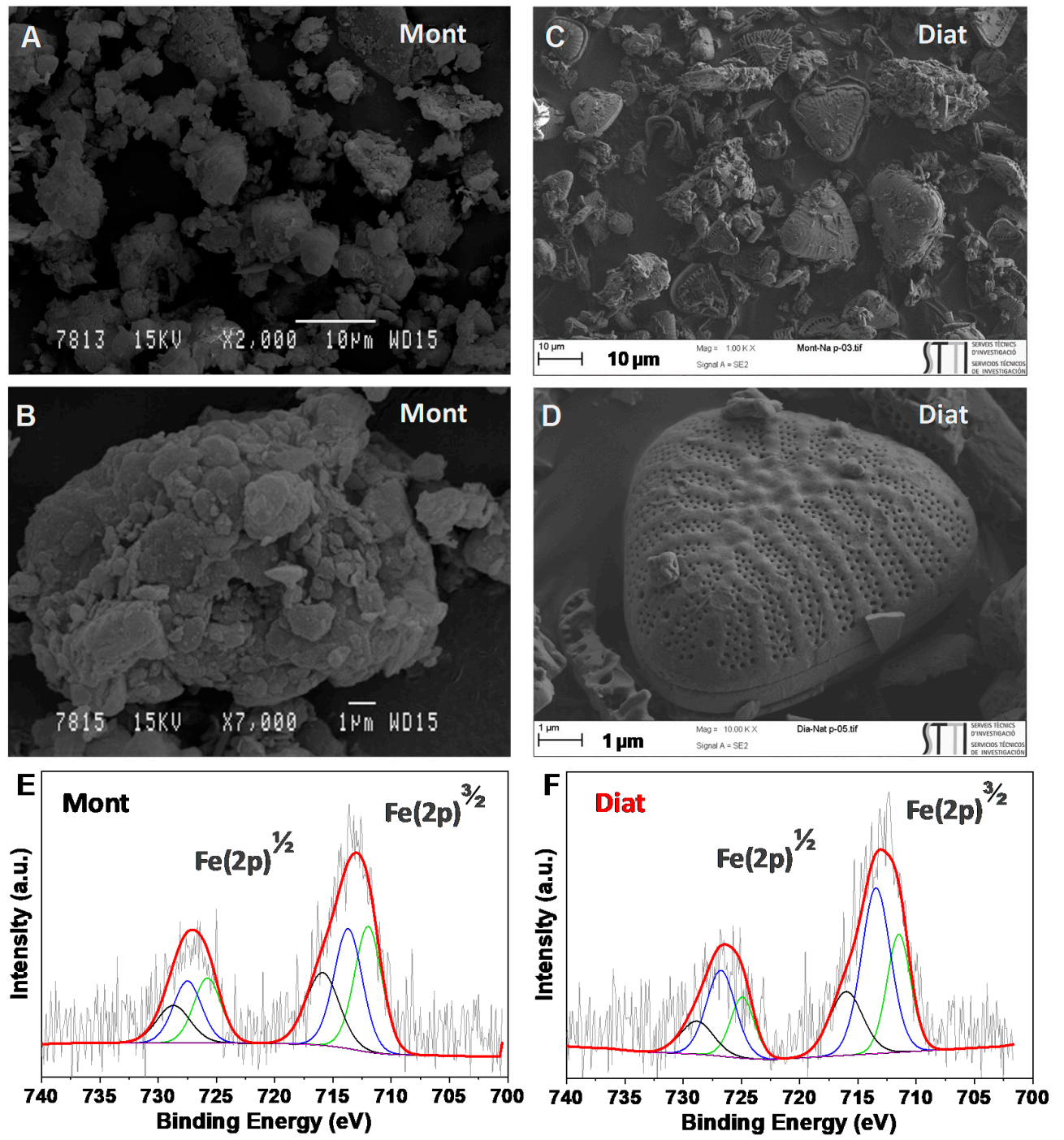

Figure 1. FE-SEM images at different magnifications of Mont $(\mathbf{A}, \mathbf{B})$ and Diat $(\mathbf{C}, \mathbf{D})$ clays (with sputter-coated C powder); and their corresponding Fe(2p) core-level XPS spectra (E and F, respectively).

Table 1 presents the chemical composition of the montmorillonite and diatomite clays obtained by XRF. Both type of materials are mainly composed of silicon (33-43 wt \%) and oxygen (46-52 wt $\%$ ), but they show different chemical composition and structure. On the one hand, the composition of the montmorillonite agrees with that of silicate hydroxides of $\mathrm{Al}$ and other substituted cations proposed for these clays [46]. As it can be observed, the studied Mont contains ca. $7 \mathrm{wt} \% \mathrm{Al}$ and a significant amount of other trivalent $(1.5 \mathrm{wt} \% \mathrm{Fe})$, divalent $(0.8 \mathrm{wt} \% \mathrm{Mg}$ and $0.4 \mathrm{wt} \% \mathrm{Ca})$ and monovalent $(2.0 \mathrm{wt} \%$ $\mathrm{K}$ and $0.2 \mathrm{wt} \% \mathrm{Na})$ metal ions. On the other hand, the Diat is mainly formed by silica hydrates $\left(\mathrm{SiO}_{2}\right.$. 
$\mathrm{nH}_{2} \mathrm{O}$ ) $[46,47]$. In the studied sample, the $\mathrm{SiO}_{2}$ content is ca. $71 \mathrm{wt} \%$ and it presents a large amount of $\mathrm{Ca}\left(\mathrm{ca} 18 \mathrm{wt} \%\right.$ ) in the form of $\mathrm{CaO}$ and $\mathrm{CaCO}_{3}$ and other minor metal species (Table 1).

Another important feature of the clays is the content and nature of iron, since it can participate in electrochemical processes (see the discussion below). Table 1 shows that the Mont contains five-fold larger iron concentration than Diat. According to XRF, the iron present in both clays is in the form of $\mathrm{Fe}_{2} \mathrm{O}_{3}$. In order to better study the chemical state of this iron, the clays were analyzed by XPS. As shown in Figure 1E,F, both samples present practically identical Fe(2p) core-level spectra, with the characteristic $\mathrm{Fe} 2 \mathrm{p}^{3 / 2}$ and $\mathrm{Fe} 2 \mathrm{p}^{1 / 2}$ spin-orbit doublet. Each component was deconvoluted and best fitted into three contributions with $2 \mathrm{p}^{3 / 2}: 2 \mathrm{p}^{1 / 2}$ height ratios of $2: 1$ and a spin orbit splitting of 13.8 or $13.4 \mathrm{eV}$ for Mont and Diat, respectively. The Fe2 $\mathrm{p}^{3 / 2}$ component with a binding energy of $711.8 \pm 0.2 \mathrm{eV}$ is assigned to Fe (II) and those at 713.6 \pm 0.1 and $716.0 \pm 0.1 \mathrm{eV}$ can be attributed to Fe (III) species, which are quite similar to those found in $\mathrm{Fe}_{3} \mathrm{O}_{4}, \mathrm{FeOOH}$ and/or $\mathrm{Fe}_{2} \mathrm{O}_{3}$ [48-50].

Table 1. Elemental composition determined by XRF and textural parameters from $\mathrm{N}_{2}$ adsorption-desorption isotherms at $-196^{\circ} \mathrm{C}$ of the different clays.

\begin{tabular}{|c|c|c|c|c|c|c|c|c|c|c|c|c|c|}
\hline & \multirow{2}{*}{\multicolumn{9}{|c|}{$\begin{array}{c}\text { X-Ray Fluorescense } \\
\text { Atomic Percentage (\%) }\end{array}$}} & \multicolumn{4}{|c|}{$\mathrm{N}_{2}$ Adsorption Isotherms } \\
\hline & & & & & & & & & & \multirow{2}{*}{$\frac{\mathrm{S}_{\mathrm{BET}}}{\mathrm{m}^{2} / \mathrm{g}}$} & \multirow{2}{*}{$\begin{array}{l}\mathrm{V}_{0.995} \\
\mathrm{~cm}^{3} / \mathrm{g}\end{array}$} & \multirow{2}{*}{$\begin{array}{l}\mathrm{V}_{\text {micro }} \\
\mathrm{cm}^{3} / \mathrm{g}\end{array}$} & \multirow{2}{*}{$\begin{array}{l}V_{\text {meso }} \\
\mathrm{cm}^{3} / \mathrm{g}\end{array}$} \\
\hline & $\mathbf{O}$ & $\mathrm{Si}$ & Al & $\mathrm{Ca}$ & Mg & $\mathrm{Sr}$ & $\mathrm{Na}$ & $\mathbf{K}$ & $\mathrm{Fe}$ & & & & \\
\hline Mont & 50.6 & 37.4 & 6.6 & 0.4 & 0.8 & 0.0 & 0.2 & 1.8 & 1.5 & 256 & 0.45 & 0.09 & 0.36 \\
\hline Diat & 46.4 & 33.2 & 0.6 & 18.2 & 0.3 & 0.3 & 0.2 & 0.2 & 0.3 & 15 & 0.05 & 0.01 & 0.06 \\
\hline
\end{tabular}

The X-ray diffraction patterns of the clay minerals are shown in Figure 2A. The Mont presents several peaks mainly associated to the hydroxy silicate crystalline structure of this material [51] and that of $\alpha$-quartz (JCPDS 00-005-0490) as the main mineral impurity. Among the clay-related diffraction peaks, some are assigned to montmorillonite mineral (Smectite group, JCPDS 00-012-0204, 00-013-0259) and many other better fit with the crystalline structure of phengite (Mica group [52]). Unlike montmorillonite, phengite is a hydroxy aluminosilicate mineral, similar to muscovite, containing also potassium and iron [52], what agrees with XRF results (Table 1). Hence, the Mont must be a mixture of montmorillonite and muscovite-like minerals [53,54]. Particularly, the weak and broad peak at ca. $2 \theta=2.7^{\circ}$ and the narrow high-intensity diffraction feature ca. $2 \theta=8.9^{\circ}$ are attributed to 001 reflections characteristic of the interlayer spacing in the montmorillonite (K10 montmorillonite) and phengite laminar structures, respectively. The laminar crystalline structure of this commercial montmorillonite was confirmed by TEM (Figure 2B), and the basal spacing was calculated as 32.8 and $9.94 \AA$ for these phases, respectively (from XRD), which are in the order of those of other similar materials reported in the literature $[55,56]$.
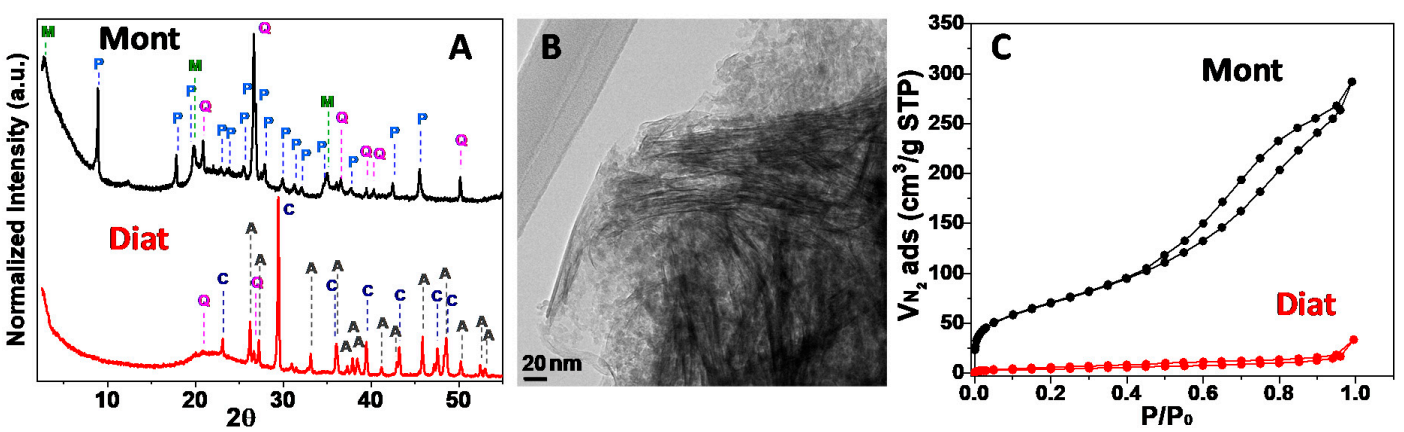

Figure 2. (A) X-ray diffraction (XRD) patterns of the clays (assignment: $\mathrm{M}=$ montmorillonite; $\mathrm{P}=$ phengite; $\mathrm{Q}=\alpha$-quartz; $\mathrm{C}=$ calcite; $\mathrm{A}=$ aragonite); $(\mathrm{B})$ transmission electron microscopy $(\mathrm{TEM})$ image of the Mont; and (C) $\mathrm{N}_{2}$ adsorption-desorption isotherms at $-196{ }^{\circ} \mathrm{C}$ of the clays. 
On the contrary, the spectrum of Diat (Figure 2A) practically exhibits the features of crystalline calcite (rhombohedral, JCPDS 00-005-0586), with the highest intensity peak at ca. $2 \theta=29.4^{\circ}$, and aragonite (orthorhombic, JCPDS 96-500-0086) polymorphs of $\mathrm{CaCO}_{3}$, with a small impurity of $\alpha$-quartz, all superimposed on a broad feature between $2 \theta=17^{\circ}$ and $30^{\circ}$ characteristic of amorphous opal $\left(\mathrm{SiO}_{2} \cdot \mathrm{nH}_{2} \mathrm{O}\right)$ [57]. This diffractogram agrees with that of other diatomites [58].

Figure $2 \mathrm{C}$ displays the $\mathrm{N}_{2}$ adsorption-desorption isotherms at $-196{ }^{\circ} \mathrm{C}$ of the different clays, and Table 1 collects the calculated textural parameters. The Mont shows a type IV isotherm, with a hysteresis loop type $\mathrm{H} 4 / \mathrm{H} 3$, characteristic of mesoporous materials with some micropores $[59,60]$; while the Diat exhibits a type I isotherm typical of macroporous materials [60]. Thus, the Mont presents much larger specific surface area and micro- and mesopore volume (Table 1) than the Diat, which contains bigger pores (see SEM images in Figure 1).

\section{Electrochemical Characterization of Clay-Modified Electrodes}

Figure $3 \mathrm{~A}$ compares the voltammetric response of GC with distinct amount of Mont deposits in $0.5 \mathrm{M} \mathrm{H}_{2} \mathrm{SO}_{4}$. All the $\mathrm{CVs}$ were found to be stable upon successive cycling, at least up to 10 cycles (see Figure $3 \mathrm{~B}$ ), inferring the good stability of the deposits. Particularly, the rectangular-like shape of the GC without any redox feature (Figure 3A) is assigned to the electrical double-layer charge (EDLC) of this material. By contrast, the GC/Mont electodes present a quite different profile, showing lower EDLC but a clear reversible redox couple with a half-wave potential $\left(\mathrm{E}_{1 / 2}\right)$ of ca. $0.46 \mathrm{~V}$ and a cathodic to anodic peak separation of $\Delta \mathrm{E}_{\mathrm{p}}=100-130 \mathrm{mV}$. Considering that the electrolyte is free of electroactive species, this redox process is assigned to the oxidation and reduction of iron species present in the Mont structure (XRF, Table 1).

Figure $3 \mathrm{~A}$ also illustrates the effect of the drops (amount) of deposited Mont on the electrochemical response of this material. It can be observed that the anodic and cathodic peak current densities increase linearly with the amount of clay up to $30 \mu \mathrm{g}$ (three drops) (see, for example, the case of the anodic peak in the inset of Figure 3A). Next, above $30 \mu \mathrm{g}$ it was found that the deposited clay partly fell down in the solution or the signal was practically the same to that of $30 \mu$ g, i.e., the peak current density reached a limit value when $30 \mu \mathrm{g}$ were deposited.

Another interesting feature was the effect of the scan rate in the voltammetric response (Figure 3C). It was found that, despite the low conductivity of a clay mineral like Mont, the anodic and cathodic peaks are well defined even at scan rates as high as $200 \mathrm{mV} / \mathrm{s}$. Furthermore, the good linear relationship up to $50 \mathrm{mV} / \mathrm{s}$ between the peak current density (see, for example, the anodic case in the inset of Figure 3C) and the scan rate reflects that the electrochemical process involves a surface-controlled process. Hence, these results indicate that, although not electrically conductive, the Mont clay is an electroactive material.

On the contrary, the electrochemical behavior of the Diat was found to be totally different (Figure 3D). Thus, unlike Mont, (i) the voltammogram of Diat is featureless by the absence of redox peaks; (ii) the registered current densities and/or voltammetric charges for Diat are even lower than those of GC support; (iii) the voltammograms for Diat appear significantly tilted; and (iv) no correlation between the voltammetric current density and the drops (amount) of Diat deposit is found. All these features reflect the non-electroactive and resistive nature of Diat deposits that block the electrochemical processes of GC surface.

Next, the electron-transfer capability of both clays was investigated with $\mathrm{Fe}^{2+} / \mathrm{Fe}^{3+}$ as a redox probe. Figure $3 \mathrm{E}$ compares the voltammograms of a Mont deposit in the presence and absence of iron in solution. In the presence of iron $\left(0.01 \mathrm{M} \mathrm{FeSO}_{4}\right)$, the voltammogram of Mont also shows the reversible redox couple, with similar onsets of the anodic and cathodic processes to those in the absence of $\mathrm{FeSO}_{4}$, but the current density and charge of both cathodic and anodic peaks as well as the peaks potential separation $\left(\Delta \mathrm{E}_{\mathrm{p}}=230 \mathrm{mV}\right)$ considerably increase. The increase in $\Delta \mathrm{E}_{\mathrm{p}}$ infers that this may be a less reversible process.

To further study this electrochemical process, the voltammograms were registered at several different scan rates (Figure 3F) and the peak current was plotted versus the square root of the scan rate. The found good linear relationship (see, for example, the anodic case in the inset of Figure 3F), 
as predicted by the classical Randles-Sevcik equation, points out that the new contribution is overall a diffusion-controlled process [61]. Consequently, the obtained results seem to indicate that electroactive Mont exhibits electron-transfer capability. In the case of Diat/GC electrode, no redox processes are observed in the voltammogram in presence of $\mathrm{Fe}(\mathrm{II})$ in the solution.

$$
j_{\text {peak }}=\left(2.69 \times 10^{5}\right) n^{3 / 2} \mathrm{AC}_{0}(D v)^{1 / 2}
$$
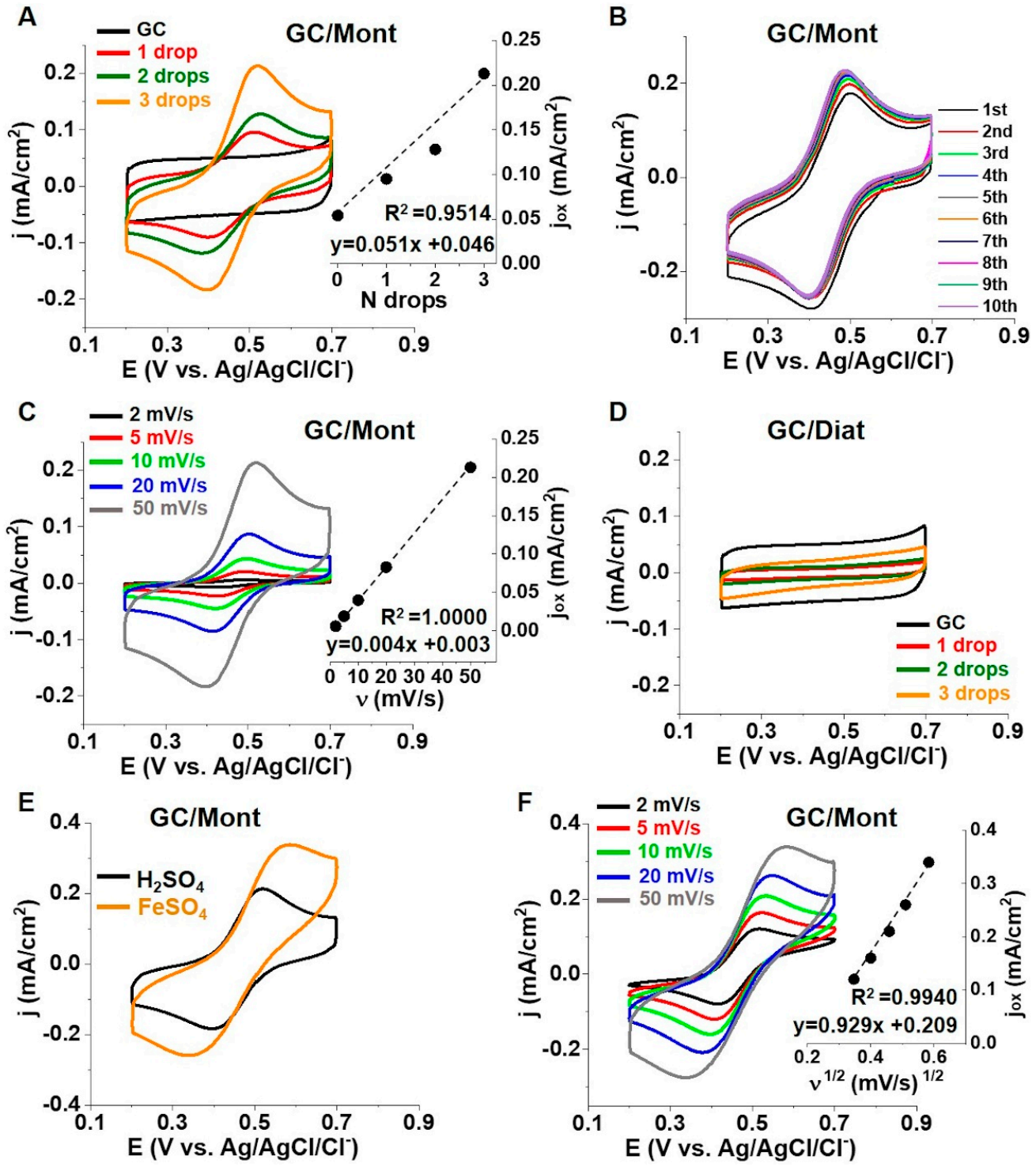

Figure 3. (A,D) Effect of drops (amount of clay) on the voltammogram (steady-state) of (A) Mont and (D) Diat in $0.5 \mathrm{M} \mathrm{H}_{2} \mathrm{SO}_{4}, \mathrm{v}=50 \mathrm{mV} / \mathrm{s}$; (B) successive voltammetric cycles of a $30 \mu \mathrm{g}$ (3 drops) deposit of Mont in $0.5 \mathrm{M} \mathrm{H}_{2} \mathrm{SO}_{4}, \mathrm{v}=50 \mathrm{mV} / \mathrm{s} ;(\mathbf{C}, \mathbf{F})$ effect of the scan rate on the voltammogram of a $30 \mu \mathrm{g}$ (3 drops) deposit of Mont in the absence $(\mathbf{C})$ or presence $(\mathbf{F})$ of dissolved iron $\left(0.01 \mathrm{M} \mathrm{FeSO}_{4}\right)$ in $0.5 \mathrm{M}$ $\mathrm{H}_{2} \mathrm{SO}_{4}$; and (E) stabilized cyclic voltammograms of a $30 \mu \mathrm{g}$ deposit of Mont in the absence or presence of dissolved iron (0.01 $\left.\mathrm{M} \mathrm{FeSO}_{4}\right)$ in $0.5 \mathrm{M} \mathrm{H}_{2} \mathrm{SO}_{4}, \mathrm{v}=50 \mathrm{mV} / \mathrm{s}$.

Figure $3 \mathrm{~F}$ also shows that the peaks potential separation $\left(\Delta \mathrm{E}_{\mathrm{p}}\right)$ progressively increases, i.e., the reversibility decreases, with the scan rate. According to the Nicholson's method [62], the standard 
rate constant $\left(K^{0}\right)$ for the electron transfer of the electrochemical reaction can be related with the so-called charge transfer parameter $(\psi)$ obtained from the $\Delta \mathrm{E}_{\mathrm{p}}$ value at suitable scan rates:

$$
K^{0}=\psi\left(\pi \frac{n F}{R T} v D\right)^{1 / 2}
$$

where $n$ is number of electrons transferred $(n=1), F$ is the Faraday constant $(96485 \mathrm{C} / \mathrm{mol}), R$ is the universal gas constant $(8.314 \mathrm{~J} / \mathrm{mol} \mathrm{K}), T$ is the reaction temperature $(298 \mathrm{~K}), v$ is the scan rate $(\mathrm{V} / \mathrm{s})$ and $D$ is the diffusion coefficient of $\mathrm{Fe}^{2+} / \mathrm{Fe}^{3+}$ (ca. $0.00000661 \mathrm{~cm}^{2} / \mathrm{s}$ [63])

Table 2 collects the main electrochemical parameters that characterize the electron transfer between the different studied materials and the $\mathrm{Fe}^{2+} / \mathrm{Fe}^{3+}$ couple. Interestingly, the reversibility (lower $\Delta \mathrm{E}_{\text {peak }}$ ) and the standard rate constant for electron transfer $\left(K^{0}\right)$ for the GC/Mont electrode are greater than for GC, and both are much better electrodes than GC/Diat, which shows neither electroactivity nor electron-transfer capability. The better electrode response of Mont compared to Diat can be attributed to (i) the higher (ca. 4.5-fold) iron concentration in Mont (see XRF results in Table 1), which has been proposed to be the origin of electroactivity; and (ii) the laminar crystalline structure and/or larger surface area of Mont (Table 1), which may facilitate a greater contact of the whole (inner) clay. From the electroactivity and good electron-transfer capability, it can be inferred that the clay Mont presents high potentiality to be used for redox and electrochemical processes.

Table 2. Anodic peak current density $\left(j_{\text {ox }}\right)$ and potential $\left(E_{\mathrm{ox}}\right)$, peak potential separation $\left(\Delta \mathrm{E}_{\mathrm{p}}\right)$, Nicholson's charge transfer parameter $(\psi)$ [62], and calculated standard rate constant $\left(K^{0}\right)$ for the electron transfer on different electroactive materials at $5 \mathrm{mv} / \mathrm{s}$ in $0.01 \mathrm{M} \mathrm{FeSO}_{4}+0.5 \mathrm{M} \mathrm{H}_{2} \mathrm{SO}_{4}$.

\begin{tabular}{lcccccc}
\hline Electrode & $\begin{array}{c}\text { PEDOT-PSS } \\
\text { Loading } \\
\mu \mathrm{g} / \mathbf{c m}^{2}\end{array}$ & $\begin{array}{c}\mathbf{j}_{\mathbf{o x}} \\
\mathbf{A} / \mathbf{c m}^{2}\end{array}$ & $\begin{array}{c}\boldsymbol{E}_{\mathbf{o x}} \\
\mathbf{V}\end{array}$ & $\begin{array}{c}\Delta \mathrm{E}_{\text {peak }} \\
\mathbf{V}\end{array}$ & $\psi$ & $\boldsymbol{K}^{0}$ \\
\hline GC & - & $2.08 \times 10^{-4}$ & 0.5419 & 148.5 & 0.23 & $4.67 \times 10^{-4}$ \\
GC/PEDOT-PSS & 562 & $1.01 \times 10^{-3}$ & 0.4889 & 65.4 & 4.60 & $9.25 \times 10^{-3}$ \\
\hline GC/Mont & - & $2.50 \times 10^{-4}$ & 0.5235 & 116.5 & 0.40 & $7.94 \times 10^{-4}$ \\
GC/Mont/PEDOT-PSS & 542 & $6.10 \times 10^{-4}$ & 0.4942 & 71.0 & 2.20 & $4.42 \times 10^{-3}$ \\
\hline GC/Diat/PEDOT-PSS & 347 & $5.95 \times 10^{-4}$ & 0.5028 & 84.2 & 0.98 & $1.97 \times 10^{-3}$ \\
\hline
\end{tabular}

\subsection{Preparation and Characterization of Clay/PEDOT-PSS Hybrid Materials}

\subsubsection{Electrochemical Polymerization}

For the electropolymerization of EDOT, the surface of the GC/clay electrodes was performed by cyclic voltammetry between $-0.4-1.0 \mathrm{~V}$ in aqueous solution containing PSS as electrolyte. The recorded cyclic voltammograms are depicted in Figure 4. Independently of the type of clay, during the first forward scan, the current densiy is roughly zero until a sharp current rise occurs above $0.85 \mathrm{~V}$. This corresponds to the onset potential of EDOT monomer oxidation and PEDOT-PSS formation [64,65]. Next, the current density remains practically invariant during the reverse scan. In successive potential cycles, the voltammograms show practically constant current between -0.4 and $0.85 \mathrm{~V}$, in both the anodic and cathodic scans, with gradually increasing voltammetric charge. These rectangle-like profiles are attributed to the double-ayer capacitive response of a growing PEDOT-PSS film on the GC/clay electrodes.

Apart from these general features of PEDOT electropolymerization, the oxidation currents and capacitive charges for the GC/Mont electrode (Figure 4A) are quite similar to those for the bare GC (figure not shown) and are considerably larger than for GC/Diat (Figure 4B). The mass of polymer formed at any cycle can be calculated from the measured double-layer charge and the theoretical specific capacitance $(\sim 70 \mathrm{~F} / \mathrm{g})$ of PEDOT $[65,66]$. Thus, the amount of PEDOT/PSS formed on the GC and GC/Mont after 35 polymerization cycles was 562 and $542 \mu \mathrm{g} / \mathrm{cm}^{2}$, respectively, whereas the 
process only yielded $347 \mu \mathrm{g} / \mathrm{cm}^{2}$ for the GC/Diat (Table 2). These results evidence a promoted growth of PEDOT on the Mont clay.
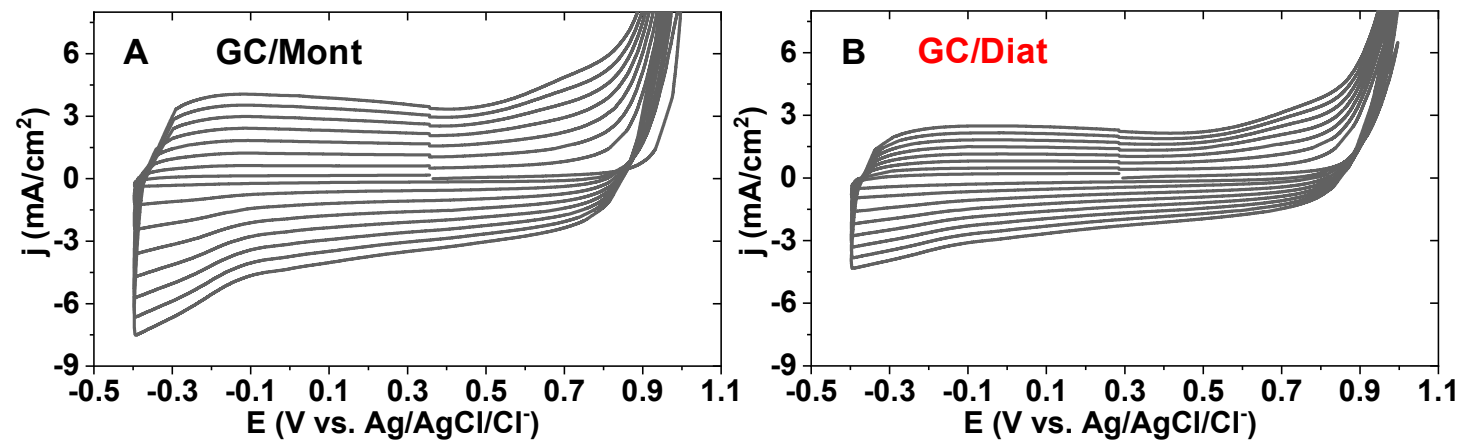

Figure 4. Successive cyclic voltammograms registered for the different GC/clay electrodes in a EDOT aqueous solution containing PSS. Anodic limit of $1.0 \mathrm{~V}$. Scan rate $=100 \mathrm{mV} / \mathrm{s}$.

Again, the better electrochemical response for the Mont material may be related to its greater electroactivity and/or its structural and textural properties. Thus, the larger volume of micropores associated to interlayer spaces in Mont may provide this material with a greater specific surface area (Table 1) to promote the polymer growth.

\subsubsection{Physico-chemical Characterization}

After electropolymerization, the surface morphology of the obtained materials was examined by FE-SEM (Figure 5). In general, both the montmorillonite (Figure 5A) and diatomite (Figure 5H) clays appeared to be covered by a thin film of a homogeneous material showing large cracks. Images of the outer surface reveal that these films are made of fine clay particles dispersed in a smooth matrix (Figure 5B,I). Nevertheless, it can be observed that the film thickness (ca. 20-40 $\mathrm{mm}$, Figure 5C) and roughness (Figure 5B) for the GC/Mont/PEDOT-PSS are greater than for the GC/Diat/PEDOT-PSS (see the thickness in Figure 5J and the roughness in Figure 5I).

EDX microanalysis (qualitative) of these materials revealed the presence of a large amount of carbon, between 5 and $25 \mathrm{wt} \%$ depending on the analyzed material and region. The fact that it was possible to take the FE-SEM images without the need for sputtering was indicative of the conductive nature of the obtained materials. Moreover, the surface chemical composition of the Mont before and after electropolymerization was analyzed by XPS (Table 3). Initially, the clay contains around 3 at $\%$ $\mathrm{C}$, which is assigned to adventitious carbon contamination, but it increases up to ca. 13 at $\% \mathrm{C}$ after the PEDOT electropolymerization. In addition, around 3 at $\% \mathrm{~S}$ was incorporated to the material as a consequence of the incorporation of thiophene rings and PSS.

The analysis of the high-resolution C(1s) and S(2p) XPS spectra (Figure 5E,F, respectively) provided crucial information about the nature of the material. On the one hand, the $\mathrm{C}(1 \mathrm{~s})$ spectrum (Figure $5 \mathrm{E}$ ) was fitted into four main contributions, namely that of $\mathrm{C}-\mathrm{C} / \mathrm{C}=\mathrm{C}$ bonds centered at $284.68 \mathrm{eV}$; that at $286.5 \mathrm{eV}$ assigned to C-S bonding; and those at 284.7 and $287.7 \mathrm{eV}$ associated with $\mathrm{C}=\mathrm{C}-\mathrm{O}$ and C-C-O environments, respectively [43,67-69]. On the other hand, two different contributions were noticed in the $S(2 p)$ spectrum (Figure $5 F$ ). The doublet with $S 2 \mathrm{p}^{3 / 2}$ at $169.1 \mathrm{eV}$ is generally associated to $\mathrm{S}-\mathrm{O} / \mathrm{S}=\mathrm{O}$ bonds in sulfonate groups $\left(\mathrm{SO}_{3}{ }^{-}\right)$, whereas that at $163.7 \mathrm{eV}$ is attributed to $\mathrm{S}-\mathrm{C}$ linkage in thiophene rings $[43,67-69]$. These features agree well with the theoretical molecular structure of PEDOT:PSS (Figure 5G) and coincide with those of other PEDOT:PSS-like materials reported in the literature $[43,67-69]$.

The ratio of both $S 2 p$ signals, the sulfonate to thiophene proportion $\left(\mathrm{S}_{(\mathrm{PSS})} / \mathrm{S}_{(\mathrm{EDOT})}\right)$ was calculated and included in Table 3. The calculated ratio is eight times higher than the stoichiometric expected one (around 1, see Figure 5G), indicating a larger proportion of PSS in respect to the thiophene rings in the obtained PEDOT-PSS fims. This effect has been comonly observed in other PEDOT-PSS films 
synthesized by electrodeposition, and has been related to the doping level of the polymer [43]. In this sense, for the electrodeposition of PEDOT-PSS on bare GC, it was previously found that the excess of PSS dopant gradually decreases with the amount/thickness of deposited polymer, obtaining a maximum value of $\mathrm{S}_{(\mathrm{PSS})} / \mathrm{S}_{(\mathrm{EDOT})}=4.1$ for extremely thin samples $\left(46.5 \mu \mathrm{g} \mathrm{cm}^{-2}\right)$ [43]. Hence, the large $\mathrm{S}_{(\mathrm{PSS})} / \mathrm{S}_{(\mathrm{EDOT})}=8.2$ value found for the studied GC/clay/PEDOT-PSS points out that its doping level is twice those of PEDOT-PSS deposited on bare GC surfaces. However, this value decreases to normal values obtained when an etching is done with $\mathrm{Ar}^{+}$, which can indicate the correct formation of the PEDOT-PSS film.
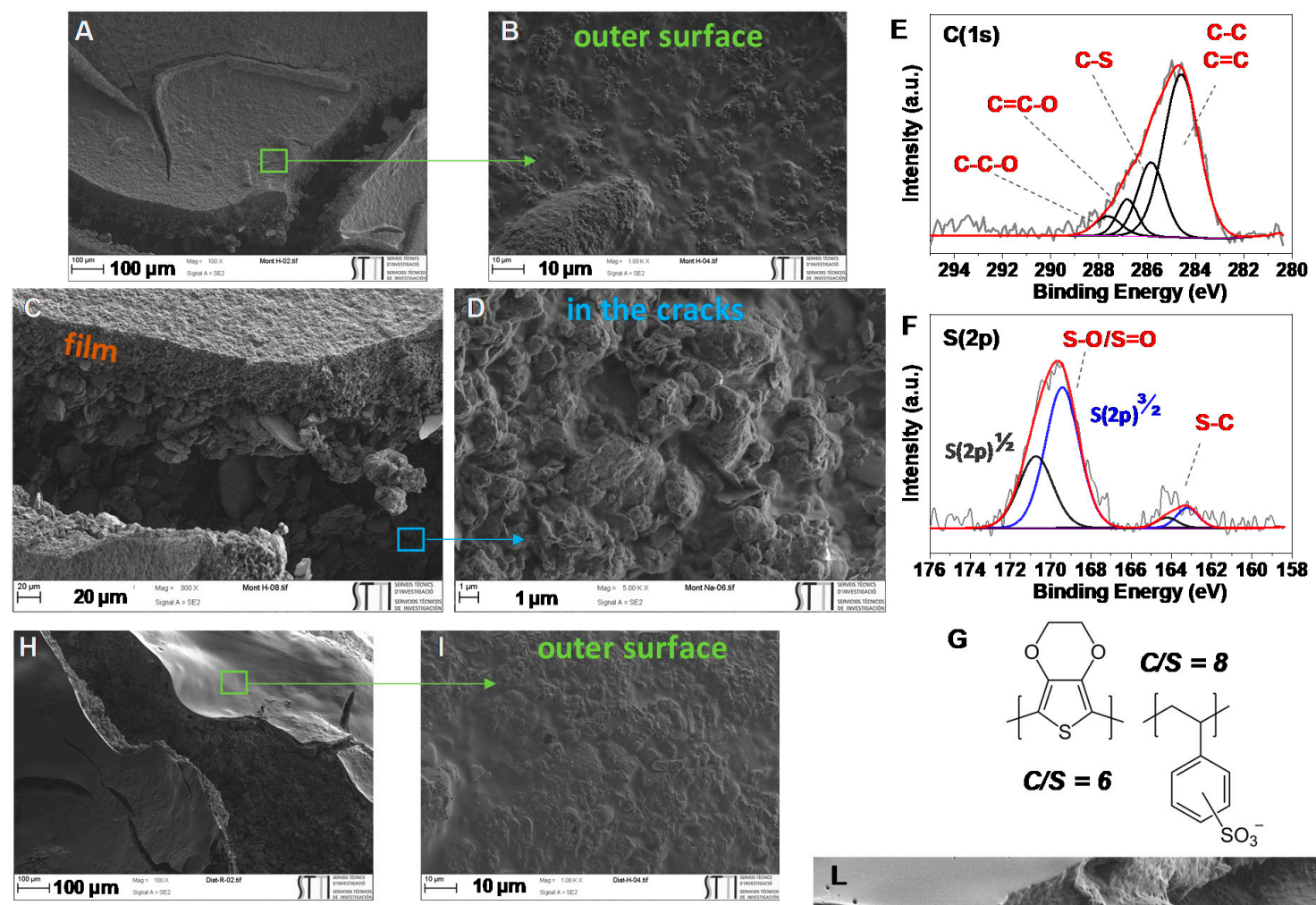

G
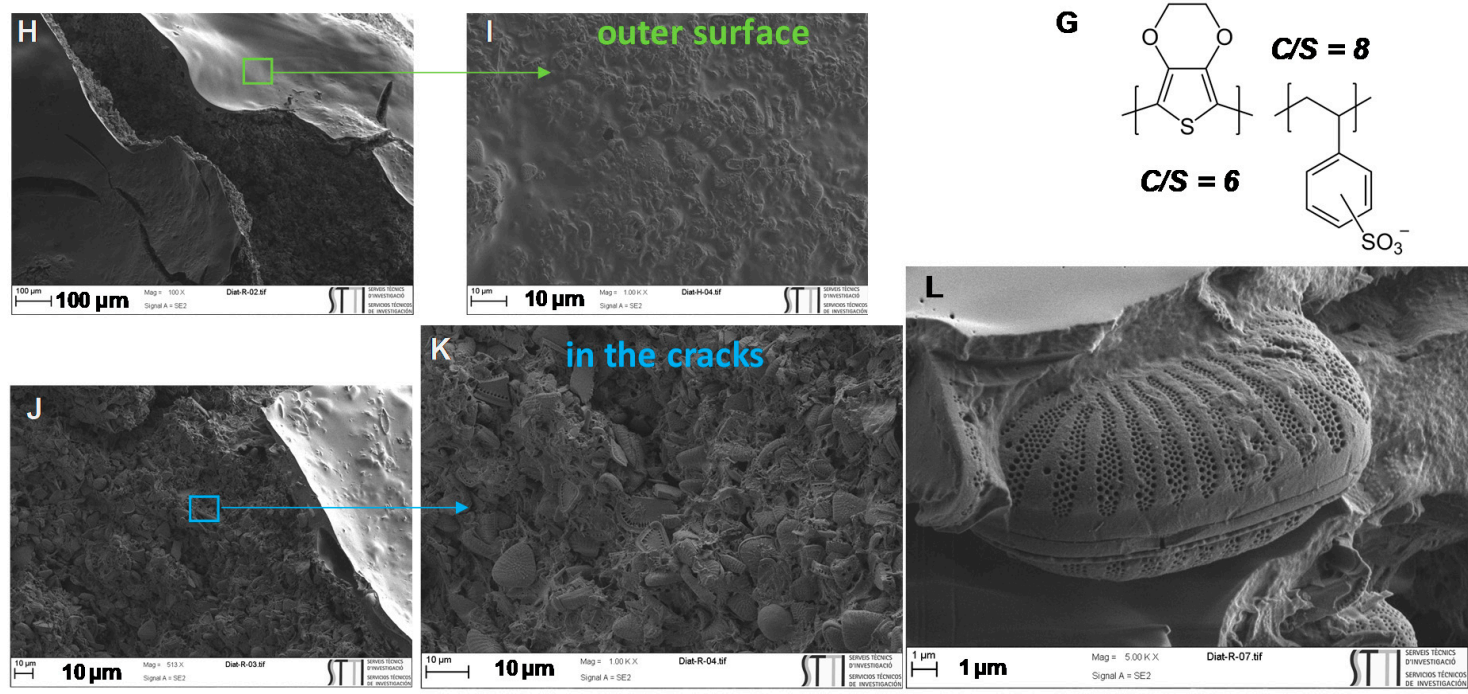

Figure 5. FE-SEM images at distinct magnifications of GC-supported Mont/PEDOT-PSS (A-D) and Diat/PEDOT-PSS (H-L); and C(1s) (E) and S(2p) (F) XPS spectra of GC-supported Mont/PEDOT-PSS prepared by electropolymerization. $(\mathbf{G})$ Theoretical chemical structure of PEDOT:PSS.

FE-SEM images inside the big cracks provided in-depth information regarding the hybrid materials. Figure 5D,K show that the inner clay particles of the deposits are uniformly covered and interconnected by a thin polymeric film. The adquirement of FE-SEM photos in these inner regions was again another piece of evidence of the presence of the conductive polymer surrounding the clay particles. Due to its low thickness, however, in this zone the polymeric film replicates the morphology of the clay particles, and thicker films are necessary to better distinguish the clay-polymer interface (Figure 5L).

In parallel, XPS analysis was repeated on the same sample after etching with Ar+ ions. This treatment removed some atomic layers (around 10-20 nm) of the outer surface over the wide 
area of XPS analysis $\left(314,000 \mu \mathrm{m}^{2}\right)$. Thus, surface etching affected both the outer thick polymer film and the cracks exposing inner particles. The $C(1 s)$ and $S(2 p)$ spectra (not shown) were found to be practically identical to those of Figure 5E,F, reflecting again the PEDOT:PSS-like nature of the polymer. Nevertheless, the overall surface content (\%) of $C$ and $S$ on the the etched sample (Mont-Na/PEDOT-PSS(etch)) significantly decreased (Table 3). This infers that the abundance of the synthesized polymer decreases with the depth of the clay deposit.

Table 3. X-ray photoelectron spectroscopy (XPS) atomic surface chemical composition of Mont clay before and after electropolymerization.

\begin{tabular}{cccccccccc}
\hline & \multicolumn{10}{c}{ Atomic \% } \\
\cline { 2 - 9 } & O & Si & Al & Fe & C & S & S $_{\text {(PSS) }}$ & S $_{\text {(EDOT) }}$ & S $_{\text {(PSS) }} / \mathbf{S}_{\text {(EDOT) }}$ \\
\hline Mont & 58.4 & 33.0 & 5.0 & 0.7 & 2.9 & - & - & - & - \\
Mont/PEDOT-PSS & 33.7 & 47.0 & 3.3 & 0.4 & 12.6 & 2.9 & 2.6 & 0.3 & 8.2 \\
Mont/PEDOT-PSS(etch) & 35.8 & 50.1 & 4.3 & 0.5 & 7.0 & 2.4 & 1.9 & 0.5 & 4.2 \\
\hline
\end{tabular}

To further study the polymer penetration and growing, one of the clay deposits was broken, so that a deeper cross-section of the material was exposed. FE-SEM micrographs (see for example the case of Diat/PEDOT-PSS in the supporting info) revealed the presence of several big channels and cracks crossing the deposit. These defects may be formed during the preparation of the deposit, probably through the release of water during IR drying, and/or by penetration of electrolyte during electropolymerization. Moreover, although to a lower extent, the polymer was detected again among the clay particles, even in this deeper part of the deposit. These results suggest that the observed channels and cracks may enable mass transportation of EDOT and PSS from the solution to the inner parts of the deposit, as well as the polymer formation throughout all the supported clay (1-2 mm thick) until the GC collector.

Finally, the effective interaction between the clay and the polymer was further demonstrated by TEM. Figure 6 presents various TEM images of the Mont/PEDOT-PSS hybrid material. Figure 6A shows an amorphous phase embedded within the clay layers, causing some exfoliation (Figure 6B). This seems to be confirmed by the decrease in the relative intensity of the characteristic diffraction peak related to laminar structure (figure not shown). Interestingly, the polymer was stable to the energetic electron beam (used in TEM) when it was inside or close to the clay particle (see the absence of holes in the polymer film during image adquisition (Figure $6 \mathrm{~A}, \mathrm{~B}$ ), or in the proximity of clay particles, zone 1 in Figure $6 \mathrm{C}$ ); but it was remarkably degraded during such exposure at a greater distance, as evidenced by the generation of round holes (zone 2 in Figure 6C). This indicates that the clay increases the stability of the polymer, as was confirmed by TG (figure not shown), thus reflecting their effective interaction.
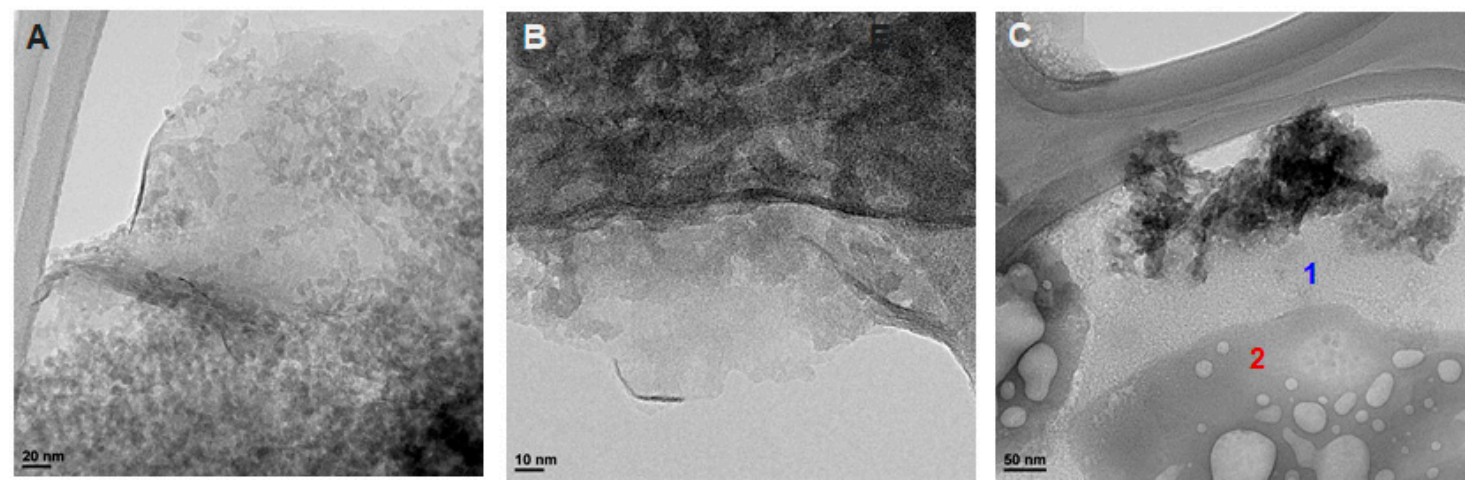

Figure 6. TEM images at different magnification of the Mont/PEDOT-PSS hybrid material.

These results point out that the polymer grew not only around but also inside the clay particles. Thus, the growth of polymer in the interlayer space of Mont may justify the higher oxidation currents and larger charge upon electropolymerization, i.e., a more effective polymer growth, observed for the 
Mont compared to the Diat (Figure 4). Hence, the different characterization techniques demonstrate the successful preparation of true hybrid materials, made of PEDOT around and/or inside the clay particles, and exhibiting effective interaction clay-PEDOT-PSS.

\subsubsection{Electrochemical Characterization}

Figure 7A,B show the effect of PEDOT-PSS on the voltammetric response of the GC/Mont and GC/Diat electrodes, respectively, in $0.5 \mathrm{M} \mathrm{H}_{2} \mathrm{SO}_{4}$. In both cases, the voltammetric currents and charges greatly increase after electropolymerization and rectangular-shape profiles are obtained. This agrees with the characteristic electrochemical response of PEDOT in an acid medium [70]. Nevertheless, the voltammetric charge of GC/Mont/PEDOT-PSS (Figure 7A) was higher than that of GC/Diat/PEDOT-PSS (Figure 7B), in agreement with the more efficient electropolymerization process observed for the Mont (see Section 3.2.1).
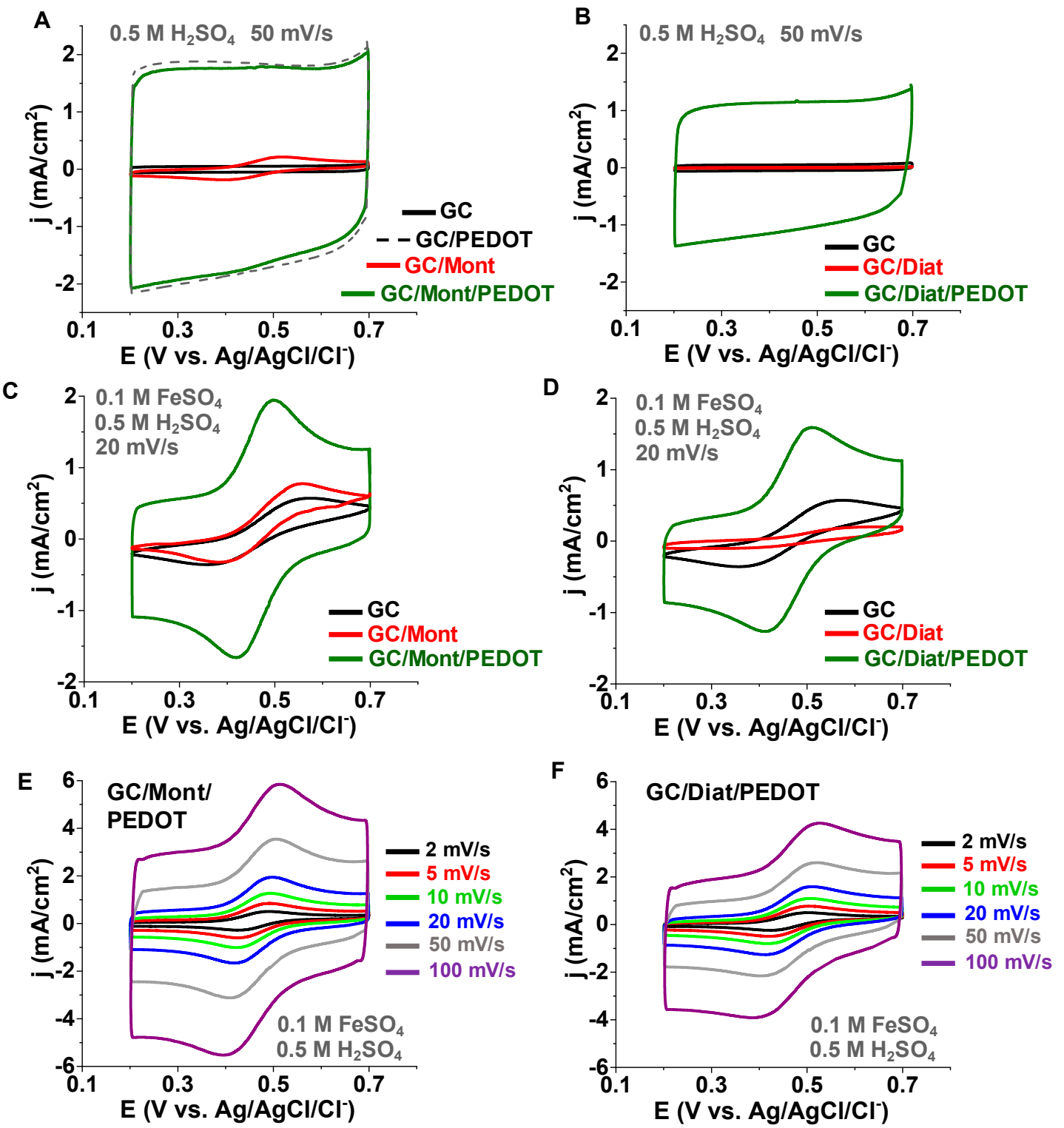

Figure 7. Steady-state cyclic voltammograms of the GC/Mont/PEDOT-PSS (A,C) and GC/Diat/PEDOT-PSS (B,D) hybrid materials in $0.5 \mathrm{M} \mathrm{H}_{2} \mathrm{SO}_{4}$ aqueous electrolyte and in the absence $(\mathbf{A}, \mathbf{B})$ or presence of $\mathrm{Fe}^{2+} / \mathrm{Fe}^{3+}$ probe $\left(0.01 \mathrm{M} \mathrm{FeSO}_{4}\right)(\mathbf{C}, \mathbf{D}) ; \mathrm{v}=20 \mathrm{mV} / \mathrm{s}$. (E,F) Effect of scan rate on the voltammetric response of GC/Mont/PEDOT-PSS (E) and GC/Diat/PEDOT-PSS (F) in the presence of $\mathrm{Fe}^{2+} / \mathrm{Fe}^{3+}$ probe $\left(0.01 \mathrm{M} \mathrm{FeSO}_{4}\right)$. 
The electron transfer capability of these hybrid materials was tested with the $\mathrm{Fe}^{2+} / \mathrm{Fe}^{3+}$ redox probe. As observed in the figure, both GC/Mont/PEDOT-PSS (Figure 7C) and GC/Diat/PEDOT-PSS (Figure 7D) show the reversible electron transfer process with $\mathrm{Fe}^{2+} / \mathrm{Fe}^{3+}$ species in solution, but the registered current densities are remarkably higher than without PEDOT-PSS. Then, the votammetric analysis was carried out at different scan rates (Figure 7E,F). The linearity between the peak current density and the square root of the scan rate confirms that the electrochemical reaction is diffusion controlled [61]. For these hybrid materials, however, the linearity was found for a wider range of scan rates than for Mont (see the GC/Mont electrode in Figure 3F). This result may be explained by the higher conductivity introduced by the incorporation of PEDOT-PSS in the hybrid materials.

On the other hand, the heterogeneous transfer rate constants $\left(K^{0}\right)$ were calculated by using the peaks' potential separation $\left(\Delta \mathrm{E}_{\mathrm{p}}\right)$ at different scan rates and by using the Equation (2). Table 2 contains the $K^{0}$ values for the hybrid materials calculated at $5 \mathrm{mV} / \mathrm{s}$. As it can be observed, the hybridization of Mont with electropolymerized PEDOT-PSS increases the electron transfer rate constant by one order of magnitude, whereas it introduces electroactivity and electron transfer capability on the inert clays (Diat). However, for similar PEDOT-PSS loadings, the GC/Mont/PEDOT-PSS composite shows a lower reaction rate constant than GC/PEDOT-PSS (Table 2), what may be reasonably explained by the poorer electrical conductivity of the clay component.

Interestingly, the quite similar $K^{0}$ values found for Mont/PEDOT-PSS and Diat/PEDOT suggest that the electron transfer kinetics on these hybrid materials are mainly determined by PEDOT-PSS. This is attributed to the high conductivity of PEDOT-PSS. Nevertheless, the clay does not seem to act as a mere support of PEDOT-PSS. Thus, the higher currents measured for the Mont/PEDOT-PSS electrode compared to Diat/PEDOT-PSS indicate that the properties of clay may have a strong influence on the polymer growth and properties, affecting the amount, dispersion, specific surface area, etc. of the polymer on the hybrid material.

\subsection{Electro-Oxidation of Diclofenac on Clay/PEDOT-PSS Hybrid Materials}

Finally, the electroxidation of diclofenac was used in this work to test the electrochemical activity of the clay/PEDOT-PSS hybrids to oxidize emerging pollutants. Figure 8A,B show the first voltammetric scans of GC/Mont/PEDOT-PSS and GC/Diat/PEDOT-PSS electrodes, respectively, in a sulfuric electrolyte containing $20 \mathrm{ppm}$ diclofenac. For comparison purposes, the figures also include the response of a GC electrode under similar conditions. It can be observed that the GC and the GC/clay/PEDOT-PSS electrodes exhibit quite different voltammetric behaviors. On the one hand, the GC electrode shows an increasing oxidation current from $1.20 \mathrm{~V}$ in the positive scan, whereas a broad reduction peak centered at ca. $0.65 \mathrm{~V}$ is clearly observed in the reverse scan from $0.95 \mathrm{~V}$. Moreover, the currents of both the anodic process and reduction peak gradually increase with diclofenac concentration, at least up to $200 \mathrm{ppm}$ diclofenac (figure not shown). Hence, the anodic current may be assigned to diclofenac oxidation, probably occurring together with water oxidation (OER) and some GC oxidation, whereas the cathodic process may be attributed to the reduction of any product generated from diclofenac oxidation.

On the other hand, for the hybrid electrodes, the onset of the oxidation current is shifted by $0.4 \mathrm{~V}$ towards lower potentials (at $0.80 \mathrm{~V}$ ) and a broad irreversible oxidation peak appears centered at ca. $1.30 \mathrm{~V}$, well separated from the OER. Moreover, an anodic hump can be discerned after the peak maximum at ca. $1.40 \mathrm{~V}$. Interestingly, the width and maximum current of this oxidation peak increase with diclofenac concentration (see an example in Figure 8C), suggesting that it may have a contribution associated to the oxidation of diclofenac on the studied clay/PEDOT-PSS hybrid materials. Nevertheless, the oxidation of the polymer and its contribution to the anodic current should not be ruled out. In this sense, the stability and mechanism of diclofenac oxidation on these clay/PEDOT-PSS hybrid materials are the subject of further research in progress. With respect to the effect of the clay, no remarkable qualitative differences were found. Again, this result suggests that the electrochemical response of these hybrid materials may be mainly governed by PEDOT-PSS. 

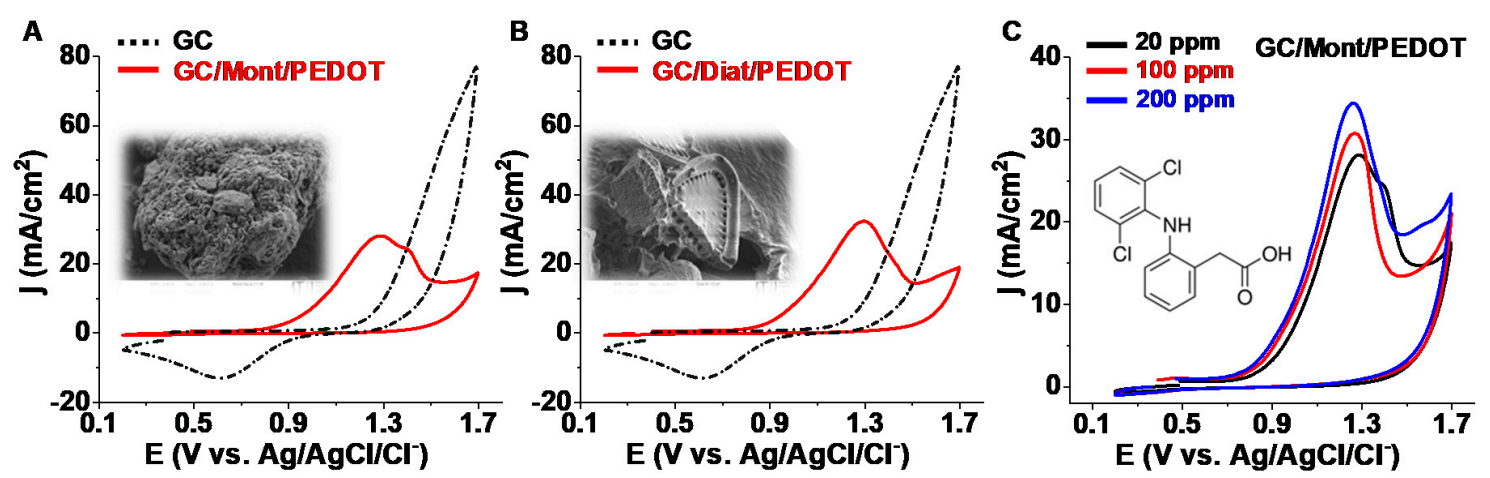

Figure 8. Voltammetric response (first scans) of the GC/Mont/PEDOT (A) and GC/Diat/PEDOT (B) hybrid materials in the presence of diclofenac (20 ppm sodium diclofenac). (C) Effect of diclofenac concentration (20-200 ppm) for GC/Mont/PEDOT (example). In all cases, the supporting electrolyte was $0.5 \mathrm{M} \mathrm{H}_{2} \mathrm{SO}_{4}$ and $\mathrm{v}=50 \mathrm{mV} / \mathrm{s}$.

To the knowedge of the authors, this study constitutes the first attempt at using clay/PEDOT-PSS hybrids for pollutants oxidation. The obtained results demonstrate the capability of these materials for diclofenac oxidation and their sensitivity to diclofenac concentration anticipates their potential utilization for sensing this or other pollutants.

\section{Conclusions}

The use of different characterization techniques indicates that the two clays studied in this work, montmorillonite and diatomite, present interesting but different physico-chemical properties. The Mont displays a laminar crystalline structure with higher micro- and mesoporosity and five-fold larger iron content than the Diat, which is essentially a non-laminar macroporous clay. The electrochemical characterization of the clays shows that the Mont exhibits a solid-state $\mathrm{Fe}^{2+} \leftrightarrow \mathrm{Fe}^{3+}$ surface reaction in $\mathrm{H}_{2} \mathrm{SO}_{4}$, that can efficiently participate in electron transfer reactions with redox species in solution, evidencing its electroactive nature. Despite its poor conductivity, the electroactivity of Mont is attributed to the iron species present in the clay $\left(F e_{\text {mont }}^{2+} / F e_{\text {mont }}^{3+}\right)$ that are located enough close to, and therefore can be effectively polarized by, the conducting current collector. On the contrary, the Diat has been found to be non-electroactive and cannot transfer electrons.

Through the electropolymerization of EDOT in the presence of PSS, clay/PEDOT-PSS hybrid materials, with a homogeneous polymer distribution and effective clay-polymer interaction, were prepared. The hybridization with PEDOT-PSS improves the electroactivity of the clays, so that it enhances the electron-transfer kinetics on Mont and it converts Diat into electroactive. Although the overall response of both hybrids is governed by PEDOT-PSS, it has been found that the nature of clay affects the electropolymerization efficiency and the electrochemical activity of the hybrids. Thus, the higher voltammetric currents measured for the Mont/PEDOT-PSS hybrid, compared to Diat/PEDOT-PSS, are assigned to the larger surface area, microporosity, laminar structure and/or electroactivity inherent to Mont clay.

Finally, the present work demonstrates that the clay/PEDOT-PSS hybrids exhibit diclofenac oxidation capability and diclofenac concentration sensitivity. Accordingly, and although optimum oxidation conditions (potentials, currents, etc.) and material stability must be further investigated, the observed electron transfer and oxidative response may be considered interesting and promising for the potential application of clays and clay hybrids in different environmental electrochemical applications.

Author Contributions: Conceptualization, R.B. and E.M.; Data curation, M.K. and R.B.; Formal analysis, F.M.; Funding acquisition, R.B., F.M. and E.M.; Investigation, M.K.; Project administration, E.M.; Resources, E.M.; Supervision, R.B. and E.M.; Validation, F.M.; Writing - original draft, M.K.; Writing - review \& editing, R.B., F.M. and E.M. All authors have read and agreed to the published version of the manuscript. 
Funding: This research was funded by Spanish Ministry of Science, Innovation and Universities (grant number RYC-2017-23618) and Generalitat Valenciana (Prometeo2018/087 project).

Conflicts of Interest: The authors declare no conflict of interest.

\section{References}

1. Zoveidavianpoor, M. Current Topics in the Utilization of Clay in Industrial and Medical Applications; IntechOpen: London, UK, 2018; ISBN 978-1-78923-729-0. [CrossRef]

2. Mukherjee, S. The Science of Clays. Applications in Industry, Engineering and Environment; Springer: Dordrecht, The Netherlands, 2013; ISBN 978-94-007-6682-2. [CrossRef]

3. Whitworth, T.M. Clay minerals: Ion exchange. In Encyclopedia of Geochemistry, 1st ed.; Marshall, C.P., Fairbridge, R.W., Eds.; Springer: Dordrecht, The Netherlands, 1998; pp. 85-87, ISBN 978-1-4020-4496-0.

4. Gupta, S.S.; Bhattacharyya, K.G. Adsorption of metal ions by clays and inorganic solids. RSC Adv. 2014, 4, 28537-28586. [CrossRef]

5. Lazaratou, C.V.; Vayenas, D.V.; Papoulis, D. The role of clays, clay minerals and clay-based materials for nitrate removal from water systems: A review. Appl. Clay Sci. 2020, 185, 105377. [CrossRef]

6. Uddin, M.K. A review on the adsorption of heavy metals by clay minerals, with special focus on the past decade. Chem. Eng. J. 2017, 308, 438-462. [CrossRef]

7. Awad, A.M.; Shaikh, S.M.R.; Jalab, R.; Gulied, M.H.; Nasser, M.S.; Benamor, A.; Adham, S. Adsorption of organic pollutants by natural and modified clays: A comprehensive review. Sep. Purif. Technol. 2019, 228, 115719. [CrossRef]

8. Dulio, V.; van Bavel, B.; Brorström-Lundén, E.; Harmsen, J.; Hollender, J.; Schlabach, M.; Slobodnik, J.; Thomas, K.; Koschorreck, J. Emerging pollutants in the EU: 10 years of NORMAN in support of environmental policies and regulations. Environ. Sci. Eur. 2018, 30,1-13. [CrossRef]

9. Rajeshwar, K.; Ibanez, J.G. Environmental Electrochemistry: Fundamentals and Applications in Pollution Abatement; Academic Press Inc.: San Diego, CA, USA, 1997; ISBN 978-0-12-576260-1.

10. Rodriguez-Narvaez, O.M.; Peralta-Hernandez, J.M.; Goonetilleke, A.; Bandala, E.R. Treatment technologies for emerging contaminants in water: A review. Chem. Eng. J. 2017, 323, 361-380. [CrossRef]

11. Sirés, I.; Brillas, E. Remediation of water pollution caused by pharmaceutical residues based on electrochemical separation and degradation technologies: A review. Environ. Int. 2012, 45, 212-229. [CrossRef]

12. Kibria, G.; Hossain, S. Electrical resistivity of compacted clay minerals. Environ. Geotech. 2017, 6, 1-8. [CrossRef]

13. Ruiz-Hitzky, E.; Aranda, P.; Darder, M.; Rytwo, G. Hybrid materials based on clays for environmental and biomedical applications. J. Mater. Chem. 2010, 20, 9306-9321. [CrossRef]

14. Ruiz-Hitzky, E.; Aranda, P.; Darder, M. Hybrid and Biohybrid Materials Based on Layered Clays. In Tailored Organic-Inorganic Materials, 1st ed.; Brunet, E., Colón, J.L., Clearfield, A., Eds.; John Wiley \& Sons, Inc.: Hoboken, NJ, USA, 2015; pp. 245-298, ISBN 9781118792223. [CrossRef]

15. Fang, F.F.; Choi, H.J.; Joo, J. Conducting polymer/clay nanocomposites and their applications. J. Nanosci. Nanotech. 2008, 8, 1559-1581. [CrossRef]

16. Gangopadhyay, R.; De, A. Conducting Polymer Nanocomposites: A Brief Overview. Chem. Mater. 2000, 12, 608-622. [CrossRef]

17. Baldissera, A.F.; Ferreira, C.A. Clay-Based Conducting Polymer Nanocomposites. In Conducting Polymer Hybrids; Springer Series on Polymer and Composite, Materials; Kumar, V., Kalia, S., Swart, H.C., Eds.; Springer International Publishing: Cham, Switzerland, 2017; pp. 143-164. [CrossRef]

18. Zhan, C.; Yu, G.; Lu, Y.; Wang, L.; Wujcik, E.; Wei, S. Conductive polymer nanocomposites: A critical review of modern advanced devices. J. Mater. Chem. C 2017, 5, 1569-1585. [CrossRef]

19. Saad, A.; Jlassi, K.; Omastová, M.; Chehimi, M.M. Clay/Conductive Polymer Nanocomposites. In Clay-Polymer Nanocomposites; Jlassi, K., Chehimi, M.M., Thomas, S., Eds.; Elsevier: Amsterdam, The Netherlands, 2017; pp. 199-237. [CrossRef]

20. Heywang, G.; Jonas, F. Poly(alkylenedioxythiophene)s-new, very stable conducting polymers. Adv. Mater. 1992, 4, 116-118. [CrossRef]

21. Groenendaal, L.; Jonas, F.; Freitag, D.; Pielartzik, H.; Reynolds, J.R. Poly(3,4-ethylenedioxythiophene) and Its Derivatives: Past, Present, and Future. Adv. Mater. 2000, 12, 481-494. [CrossRef] 
22. Skotheim, T.A.; Reynolds, J.R. Handbook of Conducting Polymers. Conjugated Polymers: Processing and Applications, 3rd ed.; CRC Press: Boca Ratón, FL, USA, 2006; ISBN 9781420043617.

23. Castagnola, V.; Bayon, C.; Descamps, E.; Bergaud, C. Morphology and conductivity of PEDOT layers produced by different electrochemical routes. Synth. Met. 2014, 189, 7-16. [CrossRef]

24. Yu, Y.-H.; Jen, C.-C.; Huang, H.-Y.; Wu, P.-C.; Huang, C.-C.; Yeh, J.-M. Preparation and properties of heterocyclically conjugated poly(3-hexylthiophene)-clay nanocomposite materials. J. Appl. Polym. Sci. 2004, 91, 3438-3446. [CrossRef]

25. Kuila, B.K.; Nandi, A.K. Physical, Mechanical, and Conductivity Properties of Poly(3-hexylthiophene)-Montmorillonite Clay Nanocomposites Produced by the Solvent Casting Method. Macromolecules 2004, 37, 8577-8584. [CrossRef]

26. Letaïef, S.; Aranda, P.; Fernandez-Saavedra, R.; Margeson, J.C.; Detellier, C.; Ruiz-Hitzky, E. Poly(3,4-ethylenedioxythiophene)-clay nanocomposites. J. Mater. Chem. 2008, 18, 2227-2233. [CrossRef]

27. Macêdo-Fonsêca, J.C.; Silva, I.S.; Souto-Maior, R.M. Poly(3-hexadecylthiophene)/montmorillonite clay nanocomposites: Influence of preparation and type of clay on their structures. Synth. Met. 2009, 159, 2215-2218. [CrossRef]

28. Hatamzadeh, M.; Jaymand, M.; Massoumi, B. Graft copolymerization of thiophene onto polystyrene synthesized via nitroxide-mediated polymerization and its polymer - clay nanocomposite. Polym. Int. 2013, 63, 402-412. [CrossRef]

29. Khalfaoui-Boutoumi, N.; Boutoumi, H.; Khalaf, H.; David, B. Synthesis and characterization of $\mathrm{TiO}_{2}-$ Montmorillonite/Polythiophene-SDS nanocomposites: Application in the sonophotocatalytic degradation of rhodamine 6G. Appl. Clay Sci. 2013, 80, 56-62. [CrossRef]

30. Han, Y.; Lu, Y. Preparation and characterization of exfoliated organic montmorillonite/poly(3,4ethyldioxythiophene) nanocomposites. J. Appl. Polym. Sci. 2009, 111, 2400-2407. [CrossRef]

31. Sarioğlan, Ş. A Comparison Study on Conductive Poly(3,4-ethylenedioxythiophene) Nanocomposites Synthesized with Clay Type Montmorillonite and Organophilic Montmorillonite. Particul. Sci. Technol. 2012, 30, 68-80. [CrossRef]

32. Ballav, N.; Biswas, M. A conducting nanocomposite via intercalative polymerisation of thiophene in montmorillonite clay. Synth. Met. 2004, 142, 309-315. [CrossRef]

33. Rajapakse, R.M.G.; Higgins, S.; Velauthamurty, K.; Bandara, H.M.N.; Wijeratne, S.; Rajapakse, R.M.M.Y. Nanocomposites of poly(3,4-ethylenedioxythiophene) and montmorillonite clay: Synthesis and characterization. J. Compos. Mater. 2010, 45, 597-608. [CrossRef]

34. Megherbi, A.; Meghabar, R.; Belbachir, M. Preparation and Characterization of Clay (Maghnite-H)/Poly(3,4-Ethylenedioxythiophene) Composites. J. Surf. Eng. Mater. Adv. Technol. 2013, 3, 21-27. [CrossRef]

35. Senarathna, K.G.C.; Randiligama, H.M.S.P.; Rajapakse, R.M.G. Preparation, characterization and oxygen reduction catalytic activities of nanocomposites of $\mathrm{Co}(\mathrm{II}) /$ montmorillonite containing polypyrrole, polyaniline or poly(ethylenedioxythiophene). RSC Adv. 2016, 6, 112853-112863. [CrossRef]

36. Mäkiniemi, R.O.; Das, P.; Hönders, D.; Grygiel, K.; Cordella, D.; Detrembleur, C.; Yuan, J.; Walther, A. Conducting, Self-Assembled, Nacre-Mimetic Polymer/Clay Nanocomposites. ACS Appl. Mater. Interf. 2015, 7, 15681-15685. [CrossRef]

37. Oriakhi, C.O.; Lerner, M.M. Poly(pyrrole) and poly(thiophene)/clay nanocomposites via latex-colloid interaction. Mater. Res. Bull. 1995, 30, 723-729. [CrossRef]

38. Kuila, B.K.; Nandi, A.K. Structural Hierarchy in Melt-Processed Poly(3-hexyl thiophene)-Montmorillonite Clay Nanocomposites: Novel Physical, Mechanical, Optical, and Conductivity Properties. J. Phys. Chem. B 2006, 110, 1621-1631. [CrossRef]

39. Kuila, B.K.; Nandi, A.K. Poly(3-dodecyl thiophene)—Organically modified montmorillonite clay nanocomposites: Influence of chain regioregularity and preparation condition on physical, mechanical, optical, and conductivity properties. J. Appl. Polym. Sci. 2009, 111, 155-167. [CrossRef]

40. Ahmad, I.; Hussain, M.; Seo, K.-S.; Choa, Y.-H. Synthesis and characterization of polymer-nanoclay conductive nanocomposites. J. Appl. Polym. Sci. 2010, 116, 314-319. [CrossRef]

41. Aradilla, D.; Estrany, F.; Azambuja, D.; Casas, M.; Puiggali, J.; Ferreira, C.A.; Alemán, C. Conducting poly(3,4-ethylenedioxythiophene)-montmorillonite exfoliated nanocomposites. Eur. Polym. J. 2010, 46, 977-983. [CrossRef] 
42. Aradilla, D.; Azambuja, D.; Estrany, F.; Casas, M.T.; Ferreira, C.A.; Alemán, C. Hybrid polythiophene-clay exfoliated nanocomposites for ultracapacitor devices. J. Mater. Chem. 2012, 22, 13110-13122. [CrossRef]

43. Djelad, H.; Huerta, F.; Morallón, E.; Montilla, F. Modulation of the electrocatalytic performance of PEDOT-PSS by reactive insertion into a sol-gel silica matrix. Eur. Polym. J. 2018, 105, 323-330. [CrossRef]

44. Lozano-Castelló, D.; Suárez-García, F.; Cazorla-Amorós, D.; Linares-Solano, A. Porous texture of carbons. In Carbons for Electrochemical Energy Storage and Conversion Systems; Beguin, F., Frackowiak, E., Eds.; CRC Press: Boca Ratón, FL, USA, 2010; pp. 115-162, ISBN 9781420053074.

45. Gonzalez, L.; Agüero, A.; Quiles-Carrillo, L.; Lascano, D.; Montanes, N. Optimization of the Loading of an Environmentally Friendly Compatibilizer Derived from Linseed Oil in Poly(Lactic Acid)/Diatomaceous Earth Composites. Materials 2019, 12, 1627. [CrossRef]

46. Weaver, C.E.; Pollard, L. The Chemistry of Clay Minerals; Elevier: Amsterdam, The Netherlands, 1973; Volume 15, ISBN 0-444-41043-0.

47. Stoermer, E.F.; Smol, J.P. The Diatoms: Applications for the Environmental and Earth Sciences, 2nd ed.; Cambridge University Press: Cambridge, UK, 2010; ISBN 978-0521509961.

48. Grosvenor, A.P.; Kobe, B.A.; Biesinger, M.C.; McIntyre, N.S. Investigation of multiplet splitting of Fe 2p XPS spectra and bonding in iron compounds. Surf. Interf. Anal. 2004, 36, 1564-1574. [CrossRef]

49. Liu, S.; Yao, K.; Fu, L.H.; Ma, M.G. Selective synthesis of $\mathrm{Fe}_{3} \mathrm{O}_{4}, \gamma-\mathrm{Fe}_{2} \mathrm{O}_{3}$, and $\alpha-\mathrm{Fe}_{2} \mathrm{O}_{3}$ using cellulose-based composites as precursors. RSC Adv. 2016, 6, 2135-2140. [CrossRef]

50. Zhang, X.; An, L.; Yin, J.; Xi, P.; Zheng, Z.; Du, Y. Effective Construction of High-quality Iron Oxy-hydroxides and Co-doped Iron Oxy-hydroxides Nanostructures: Towards the Promising Oxygen Evolution Reaction Application. Sci. Rep. 2017, 7, 43590. [CrossRef]

51. Brindley, G.W.; Brown, G. Crystal Structures of Clay Minerals and Their X-Ray Identification; Mineralogical Society of Great Britain and Ireland: London, UK, 1980; ISBN 9780903056373. [CrossRef]

52. Mookherjee, M.; Redfern, S.A.T.; Zhang, M. Thermal response of structure and hydroxyl ion of phengite-2M1: An in situ neutron diffraction and FTIR study. Eur. J. Mineral. 2001, 13, 545-555. [CrossRef]

53. Marsh, A.; Heath, A.; Patureau, P.; Evernden, M.; Walker, P. Alkali activation behaviour of un-calcined montmorillonite and illite clay minerals. Appl. Clay Sci. 2018, 166, 250-261. [CrossRef]

54. Alekseeva, O.; Noskov, A.; Grishina, E.; Ramenskaya, L.; Kudryakova, N.; Ivanov, V.; Agafonov, A. Structural and Thermal Properties of Montmorillonite/Ionic Liquid Composites. Materials 2019, 12, 2578. [CrossRef] [PubMed]

55. Bhattacharyya, K.G.; Gupta, S.S. Kaolinite, montmorillonite, and their modified derivatives as adsorbents for removal of $\mathrm{Cu}(\mathrm{II})$ from aqueous solution. Sep. Purif. Technol. 2006, 50, 388-397. [CrossRef]

56. Gupta, S.S.; Bhattacharyya, K.G. Immobilization of $\mathrm{Pb}(\mathrm{II}), \mathrm{Cd}(\mathrm{II})$ and $\mathrm{Ni}(\mathrm{II})$ ions on kaolinite and montmorillonite surfaces from aqueous medium. J. Environ. Manag. 2008, 87, 46-58. [CrossRef]

57. Samoilovich, M.I.; Rinkevich, A.B.; Bovtun, V.; Belyanin, A.F.; Kempa, M.; Nuzhnyy, D.; Tsvetkov, M.Y.; Kleshcheva, S.M. Optical, Magnetic, and Dielectric Properties of Opal Matrices with Intersphere Nanocavities Filled with Crystalline Multiferroic, Piezoelectric, and Segnetoelectric Materials. Russ. J. Gen. Chem. 2013, 83, 2132-2147. [CrossRef]

58. Pavía, H.; Velosa, A.; Cachim, P.; Ferreira, V.M. Effect of pozzolans with different physical and chemical characteristics on concrete properties. Mater. Construcc. 2016, 66, e083. [CrossRef]

59. Zehhaf, A.; Benyoucef, A.; Berenguer, R.; Quijada, C.; Taleb, S.; Morallón, E. Lead ion adsorption from aqueous solutions in modified Algerian montmorillonites. J. Therm. Anal. Calorim. 2012, 110, 1069-1077. [CrossRef]

60. Sing, K.S.W.; Everett, D.H.; Haul, R.A.W.; Moscou, L.; Pierotti, R.A.; Rouquerol, J.; Siemieniewska, T. Reporting physisorption data for gas/solid systems with special reference to the determination of surface area and porosity. Pure Appl. Chem. 1985, 57, 603-619. [CrossRef]

61. Bard, A.J.; Faulkner, L.R. Electrochemical Methods: Fundamentals and Applications, 2nd ed.; John Wiley\& Sons: New York, NY, USA, 2001; ISBN 0-471-04372-9.

62. Nicholson, R.S. Theory and Application of Cyclic Voltammetry for Measurement of Electrode Reaction Kinetics. Anal. Chem. 1965, 37, 1351-1355. [CrossRef]

63. Buffle, J.; Zhang, Z.; Startchev, K. Metal Flux and Dynamic Speciation at (Bio)interfaces. Part I: Critical Evaluation and Compilation of Physicochemical Parameters for Complexes with Simple Ligands and Fulvic/Humic Substances. Environ. Sci. Technol. 2007, 41, 7609-7620. [CrossRef] 
64. Djelad, H.; Benyoucef, A.; Morallón, E.; Montilla, F. Reactive Insertion of PEDOT-PSS in SWCNT@Silica Composites and its Electrochemical Performance. Materials 2020, 13, 1200. [CrossRef] [PubMed]

65. Bobacka, J.; Lewenstam, A.; Lvaska, A. Electrochemical impedance spectroscopy of oxidized poly(3,4-ethylenedioxythiophene) film electrodes in aqueous solutions. J. Electroanal. Chem. 2000, 489, 17-27. [CrossRef]

66. López-Bernabeu, S.; Huerta, F.; Morallón, E.; Montilla, F. Direct Electron Transfer to Cytochrome c Induced by a Conducting Polymer. J. Phys. Chem. C 2017, 121, 15870-15879. [CrossRef]

67. Farah, A.A.; Rutledge, S.A.; Schaarschmidt, A.; Lai, R.; Freedman, J.P.; Helmy, A.S. Conductivity enhancement of poly(3,4-ethylenedioxythiophene)-poly(styrenesulfonate) films post-spincasting. J. Appl. Phys. 2012, 112, 113709. [CrossRef]

68. Du, F.P.; Cao, N.N.; Zhang, Y.F.; Fu, P.; Wu, Y.G.; Lin, Z.D.; Shi, R.; Amini, A.; Cheng, C. PEDOT:PSS/graphene quantum dots films with enhanced thermoelectric properties via strong interfacial interaction and phase separation. Sci. Rep. 2018, 8, 6441. [CrossRef]

69. Santos, B.P.S.; Arias, J.J.R.; Albuquerque, L.S.; da Veiga, A.G.; Furtado, J.G.M.; Ribeiro, A.C.; Silva, L.A.F.; Bendinelli, E.V.; Rocco, M.L.M.; Valaski, R.; et al. An investigation on the effect of the monomer/catalyst ratio in the electronic properties of poly(3-hexylthiophene) using XPS, REELS and UPS techniques. J. Electron Spectros. Relat. Phenom. 2019, 234, 27-33. [CrossRef]

70. Zalka, D.; Kovács, N.; Szekeres, K.; Újvári, M.; Vesztergom, S.; Eliseeva, S.; Kondratiev, V.; Láng, G.D. Determination of the charge transfer resistance of poly(3,4-ethylenedioxythiophene)-modified electrodes immediately after overoxidation. Electrochim. Acta 2017, 247, 321-332. [CrossRef]

(C) 2020 by the authors. Licensee MDPI, Basel, Switzerland. This article is an open access article distributed under the terms and conditions of the Creative Commons Attribution (CC BY) license (http://creativecommons.org/licenses/by/4.0/). 